\title{
Serum Protects Cells and Increases Intracellular Delivery of Molecules by Nanoparticle-Mediated Photoporation
}

\author{
Simple Kumar (D) \\ Eunice Lazau (iD) ${ }^{2}$ \\ Carter $\mathrm{Kim}^{2}$ \\ Naresh $\mathrm{N}$ Thadhani $^{3}$ \\ Mark R Prausnitz (D) \\ 'School of Chemical and Biomolecular \\ Engineering, Georgia Institute of \\ Technology, Atlanta, GA, 30332, USA; \\ ${ }^{2}$ School of Chemistry and Biochemistry, \\ Georgia Institute of Technology, Atlanta, \\ GA, 30318, USA; ${ }^{3}$ School of Materials \\ Science and Engineering, Georgia \\ Institute of Technology, Atlanta, GA, \\ 30332, USA
}

Introduction: Intracellular delivery of molecules is central to applications in biotechnology, medicine, and basic research. Nanoparticle-mediated photoporation using carbon black nanoparticles exposed to pulsed, near-infrared laser irradiation offers a physical route to create transient cell membrane pores, enabling intracellular delivery. However, nanoparticlemediated photoporation, like other physical intracellular delivery technologies, necessitates a trade-off between achieving efficient uptake of exogenous molecules and maintaining high cell viability.

Methods: In this study, we sought to shift this balance by adding serum to cells during nanoparticle-mediated photoporation as a viability protectant. DU-145 prostate cancer cells and human dermal fibroblasts were exposed to laser irradiation in the presence of carbon black (CB) nanoparticles and other formulation additives, including fetal bovine serum (FBS) and polymers.

Results: Our studies showed that FBS can protect cells from viability loss, even at highfluence laser irradiation conditions that lead to high levels of intracellular delivery in two different mammalian cell types. Further studies revealed that full FBS was not needed: viability protection was achieved with denatured FBS, with just the high molecular weight fraction of FBS (>30 kDa), or even with individual proteins like albumin or hemoglobin. Finally, we found that viability protection was also obtained using certain neutral watersoluble polymers, including Pluronic F127, polyvinylpyrrolidone, poly(2-ethyl-2-oxazoline), and polyethylene glycol, which were more effective at increased concentration, molecular weight, or hydrophobicity.

Conclusion: Altogether, these findings suggest an interaction between amphiphilic domains of polymers with the cell membrane to help cells maintain viability, possibly by facilitating transmembrane pore closure. In this way, serum components or synthetic polymers can be used to increase intracellular delivery by nanoparticle-mediated photoporation while maintaining high cell viability.

Keywords: drug delivery, carbon black nanoparticle, photoporation, polymer, cell viability

\section{Introduction}

Intracellular delivery of molecules is of widespread interest for a variety of applications including genetic manipulation of cells, delivery of drugs with intracellular targets, bio-imaging, and molecular biology studies. ${ }^{1,2}$ The plasma membrane, which is made of phospholipids that are amphipathic ${ }^{3}$ and block the transmembrane movement of compounds into cells, offers significant resistance to intracellular delivery. There are bulk transport mechanisms, eg, endocytosis ${ }^{4}$ that move material
Correspondence: Mark R Prausnitz Ford Environmental Science \& Technology Building, 3 II Ferst Drive NW, Atlanta, GA, 30332, USA

Tel $+|404894-5| 35$

$\mathrm{Fax}+|404894-229|$

Email prausnitz@gatech.edu 
across the cell membrane; however, these active-transport pathways often damage the material being delivered, due to $\mathrm{pH}$ change and enzymatic degradation in endosomes, thereby disrupting and/or completely preventing interaction with target molecule(s) in desired form. ${ }^{5,6}$

Numerous technologies have been developed to facilitate intracellular delivery of molecules. Researchers have explored biological (eg, viral vectors), ${ }^{7}$ chemical (eg, polymeric and particulate vectors) ${ }^{8}$ and physical (eg, microinjection, gene gun, sonoporation, electroporation) ${ }^{9}$ methods to design efficient intracellular delivery processes. Although these methods can be effective, concerns remain regarding immunogenicity, toxicity, limited efficiency, low cell viability, and restricted application., ${ }^{7,10}$

Nanoparticle-mediated photoporation provides an alternative to current delivery methods. When a suspension of nanoparticles, such as carbon black (CB), with cells and drug molecules gets irradiated by a laser beam, the nanoparticles absorb energy delivered by laser and dissipate it as heat and photoacoustic waves as well as fluid flow. This concentrated release of energy from the nanoparticles is believed to create transient pores in cell membranes, allowing molecules to pass into the cytosol without killing the cell. ${ }^{11-13}$ Additional nanoparticle materials such as nanotubes, gold and others have also been used in the context of photothermal ablation, imaging and drug delivery, however with varied efficiencies. ${ }^{14-16}$

Previously, researchers performed studies to elucidate the mechanism involved during photoporation and optimize the process for efficient intracellular delivery. ${ }^{12,13,15,17-19}$ However, large percentages of cells become non-viable at higher laser fluence due to irreversible cell damage. ${ }^{18}$ Increased viability loss is common with physical delivery methods that apply external stress to cell membranes to create transient pores. ${ }^{20,21}$ Irreversible cell damage can have applications in targeted ablation of undesirable tissues such as cancerous tumors. ${ }^{22}$ However, cell viability loss becomes disadvantageous for intracellular delivery applications meant for research, diagnostic, or therapeutic purposes. Most mitigation strategies revolve around using lower laser fluence or reducing external stress exposure duration, which can limit the percentage of cells with molecular uptake.

Therefore, to increase the percentage of cells with molecular uptake at high laser fluence in nanoparticlemediated photoporation, we propose using serum as a cell viability protection additive. This is relevant not only to in vitro scenarios where serum can be added, but also to in vivo settings where extracellular fluid may resemble serum. We hypothesize that the presence of serum in cell suspension media during photoporation will increase percentages of viable cells resulting in higher intracellular uptake. Fetal bovine serum (FBS) has previously been used to protect cell viability against fluid mechanical damage in bioreactors ${ }^{23,24}$ and during electroporation, ${ }^{25}$ as well as to increase drug delivery efficiency in other contexts, ${ }^{26,27}$ and thus has promise as a viability protection additive. Cellular viability loss has been a common issue for large-scale suspension cell culture in sparged and agitated bioreactors since the $1960 \mathrm{~s}^{28}$ Observed cell damage was attributed to increased local shear near the cell membrane, caused by bubble breakup at the free surface of these bioreactors and draining foams. ${ }^{28} \mathrm{FBS}$ and certain polymers were thus introduced as viability protective agents against the shear damage seen in suspension cell culture. However, these mechanisms of energy transfer and cell damage differ from nanoparticle-mediated photoporation.

Hence, this study was designed to investigate the effect of serum addition in cell suspension media during photoporation and further explore the physical and biochemical interactions brought about by serum introduction.

\section{Materials and Methods Cell Preparation}

DU145 human prostate carcinoma cells (American Type Culture Collection, Manassas, VA) were grown in tissue culture flasks with cell media containing Roswell Park Memorial Institute (RPMI) 1640 medium (Cellgro, Herndon, VA), with $10 \%$ v/v FBS (Corning, Palo Alto, $\mathrm{CA}$ ) and $10 \mathrm{~mL}$ penicillin-streptomycin (Cellgro). Human dermal fibroblast cells (Thermo Fisher Scientific, Waltham, MA) were grown in tissue culture flasks containing Dulbecco's Modified Eagle's Medium (DMEM) (Gibco, Dublin, Ireland), supplemented with $10 \% \mathrm{v} / \mathrm{v}$ FBS and $1 \% \mathrm{v} / \mathrm{v} \mathrm{P} / \mathrm{S}$. Each cell type was incubated at $37^{\circ} \mathrm{C}, 5 \% \mathrm{CO}_{2}$, and $98 \%$ relative humidity levels during the growth period. Cells were cultured at $85 \%$ confluency using $0.25 \%$ trypsin/EDTA (Cellgro). After harvesting, DU145 cells were suspended in RPMI and human dermal fibroblast cells were suspended in DMEM (unless otherwise mentioned) at a concentration of $10^{6}$ cells $/ \mathrm{mL}$. 


\section{Nanoparticle Dispersion Preparation}

CB nanoparticle dispersions were prepared by adding 25 $\mathrm{nm}$ diameter CB nanoparticles (Black Pearls 470, Cabot, Boston, MA) at a concentration of $400 \mathrm{mg} / \mathrm{L}$ to DI water containing $\quad 0.013 \% \quad(\mathrm{v} / \mathrm{v})$ Tween-80 (Sigma-Aldrich, St. Louis, MO) to enhance solution stability (ie, prevent particle aggregation for a homogeneous dispersion). The solution was first sonicated for $35 \mathrm{~min}$ in an ultrasonic water bath (FS3OH, Fisher Scientific, Pittsburg, PA) and then with an ultrasonic needle for 1 min (Sonics Ultracell, Sonics \& Materials, Newton, CT). CB nanoparticles tend to aggregate in aqueous dispersions and thus the final aggregate diameter was measured to be $195 \mathrm{~nm}$ using dynamic light scattering (DLS) measurements (ZetaSizer Nano, Malvern Instruments, Malvern, UK).

\section{Cell Suspension Media Preparation}

Cell suspension media were prepared by adding FBS, bovine serum albumin (BSA), hemoglobin, polyethylene glycol (PEG, 10000-600000 Mw), poly (N-(2-hydroxypropyl) methacrylamide) (PHPMA, 47500 $\mathrm{Mw}$ ), polyvinylpyrrolidone (PVP, 10000-360000 Mw), poly(2-ethyl-2-oxazoline) (PEOX, $50000 \mathrm{Mw}$ ), or Pluronic F127 (Sigma Aldrich, St. Louis, MO) in RPMI. The polymer solutions were sonicated in a water bath for 5 min before use to dissolve and homogenize the polymer solution. After this, cells were added to the polymer solution immediately after harvesting to make a suspension of cells at a concentration of $10^{6}$ cells $/ \mathrm{mL}$.

\section{FBS Protein Denaturation}

Denatured protein suspensions were prepared in two ways. Using thermal denaturation, FBS solution was heated in a water bath at temperature of $100^{\circ} \mathrm{C}$ for $60 \mathrm{~min}^{29} \mathrm{Via}$ mechanical denaturation using ultrasonic needle (Sonics Ultracell, Sonics \& Materials, Newton, CT), FBS solution was sonicated for 40 rounds of sonication with 5 pulses of $1 \mathrm{sec}$ (at $20 \mathrm{kHz}$, delivering maximum of 50 Watts power) in each round followed by $1 \mathrm{~min}$ of incubation period at ambient temperature. ${ }^{30}$ Both were then added to RPMI to prepare appropriate concentrations of FBS solution.

\section{Exposure Sample Preparation and Laser Exposure}

Exposure samples were prepared by mixing $520 \mu \mathrm{L}$ of DU145 cells $\left(10^{6} / \mathrm{mL}\right)$ suspended in RPMI or other cell suspension media mentioned above, $37 \mu \mathrm{L}$ of $400 \mathrm{mg} / \mathrm{L}$
$\mathrm{CB}$ dispersion, and $5.5 \mu \mathrm{L}$ of $1 \mathrm{mM}$ calcein (Molecular Probes, Eugene, OR) solution in a $1.5 \mathrm{~mL}$ Eppendorf tube. The final CB nanoparticle concentration was $26.3 \mathrm{mg} / \mathrm{L}$ and the calcein concentration was $10 \mu \mathrm{M}$. Samples were stored in ice baths to reduce endocytosis/cellular activity before and after laser exposure.

Samples were all prepared at the same time, and then sequentially exposed to laser irradiation within $2-3 \mathrm{~h}$ after sample preparation. To perform laser irradiation, cell samples were transferred to a $2 \mathrm{~mm}$ wide and $21 \mathrm{~mm}$ diameter cylindrical Pyrex glass cuvette (37-PX-2, Starna Cells, Atascadero, CA) for laser exposure. An Nd:YAG solidstate laser (Continuum PowerLite II Plus, Continuum, San Jose, CA) was used to apply 5-9 ns pulses of $1064 \mathrm{~nm}$ wavelength at a frequency of $10 \mathrm{~Hz}$ for a duration of 1 min. Laser fluence was varied between 25 and $88 \mathrm{~mJ} / \mathrm{cm}^{2}$. Samples were exposed to a $21 \mathrm{~mm}$ diameter laser beam, which irradiated the whole surface with a flat top (ie, uniform) energy profile. Immediately after exposure, samples were transferred back to the Eppendorf tubes and stored on ice for up to $2 \mathrm{~h}$ before analysis was complete. When serum was added after laser exposure, the cell, CB nanoparticle and calcein concentrations were the same as in other experiments, and were diluted by addition of $10 \%$ serum after laser exposure.

Negative controls in the form of "sham" exposures were samples containing cells, CB nanoparticles, and calcein that experienced the same handling and procedures minus the laser exposure. To label non-viable cells post laserirradiation, propidium iodide (PI) (Invitrogen, Grand Island, NY) was added at a final concentration of $13.4 \mu \mathrm{M}$ and incubated for $10 \mathrm{~min}$ on ice. Cell samples were then centrifuged at $500 \mathrm{~g}$ for $6 \mathrm{~min}$ and washed with phosphate buffer saline (PBS) three times to remove excess calcein from the bulk solution before analysis. During this process, cells remained suspended with $\mathrm{CB}$ nanoparticles and calcein molecules from initial sample preparation until being washed with PBS before flow cytometry analysis, which totaled $2-4 \mathrm{~h}$.

\section{Data Collection}

Cells were analyzed using a bench-top flow cytometer (BD Accuri, BD Biosciences, San Jose, CA) to quantify bioeffects in terms of cell viability (based on red PI fluorescence) and intracellular uptake (based on green calcein fluorescence). Calcein fluorescence was measured using a 530/28 nm bandpass filter with excitation at $488 \mathrm{~nm}$ and PI fluorescence was measured using a $670 \mathrm{~nm}$ longpass filter with excitation at $535 \mathrm{~nm}$. Cell samples were 
run at a constant flow rate of $35 \mu \mathrm{L} / \mathrm{min}$ for $1 \mathrm{~min}$. Cells with calcein fluorescence greater than a threshold determined in sham cells incubated in calcein and PI but not exposed to laser irradiation were considered to have intracellular uptake; the threshold was selected such that $<5 \%$ of cells in sham samples were above the threshold. Cells with PI fluorescence greater than that observed in sham cells were considered to be non-viable.

A negative control containing only cells in RPMI was used to construct a cell population gate in the forwardscattered and side-scattered analyses. Cells within this gate were considered to be intact cells. To account for possible cell loss due to cell fragmentation (appearing as low forward-scatter and low side-scatter events on the flow cytometer), the difference between the number of viable plus non-viable intact cells detected in a given sample and the number of viable cells detected in sham samples was taken as the number of cells lost to fragmentation. The following equations were used to characterize the populations of different types of cells determined by flow cytometry.

$$
\begin{gathered}
\% \text { viable cells }=\frac{(\text { viable cell count })_{\text {sample }}}{(\text { viable cell count })_{\text {sham }}} \times 100 \% \\
\% \text { uptake cells }=\frac{(\text { uptake cell count })_{\text {sample }}}{(\text { viable cell count })_{\text {sham }}} \times 100 \% \\
\% \text { non }- \text { viable cells }=\frac{(\text { non }- \text { viable cell count })_{\text {sample }}}{(\text { viable cell count })_{\text {sham }}} \\
\times 100 \%
\end{gathered}
$$$$
\begin{aligned}
\% \text { deadcells }= & \frac{(\text { viablecell count })_{\text {sham }}-(\text { viablecellcount })_{\text {sample }}}{(\text { viablecell }, \text { count })_{\text {sham }}} \\
& \times 100 \% \quad
\end{aligned}
$$

$\%$ fragmented cells $=\%$ dead cells $-\%$ non - viable cells

where a "cell" is an event on the flow cytometer with light scattering characteristics consistent with cells as determined in untreated cell samples, "uptake cells" are cells with fluorescence greater than the threshold value, "nonviable cells" are cells with propidium iodide staining, "viable cells" are cells without propidium iodide staining, "fragmented cells" are cells that no longer appear as cells on the flow cytometer (ie, accounted for as described above) and "dead cells" are the sum of non-viable cells and fragmented cells. The subscript "sham" refers to samples that received a sham exposure as described above and the subscript "sample" refers to sample exposure to laser irradiation. The viable cell count in sham samples was typically $>95 \%$ of the cells and the uptake cell count in sham samples was typically $<5 \%$ of the cells, irrespective of the presence of serum, polymers of other additives.

\section{Data Analysis}

A minimum of 3 replicates were used for each experimental condition. Mean and standard error of the mean (SEM) were calculated using the three replicates. One-way analysis of variance (ANOVA, $\alpha=0.05$ ) was performed to compare three or more experimental conditions using GraphPad Prism 8 (GraphPad Software, La Jolla, CA) followed by post-hoc Tukey's pairwise comparison. A value of $\mathrm{p}<0.05$ was considered statistically significant.

\section{Results}

\section{Effects of Serum Addition on Cellular Bio-Effects During Photoporation}

To evaluate the effect of serum on nanoparticle-mediated photoporation, cells were suspended in RPMI alone or RPMI containing up to $15 \% \mathrm{v} / \mathrm{v}$ FBS in the presence of $\mathrm{CB}$ nanoparticles and calcein, and then exposed to nanosecond-pulsed laser. Using flow cytometry, cells were found to fall into one of four categories with increasing degrees of bio-effects: viable cells with little or no intracellular uptake of the marker (ie, no fluorescent staining); viable cells containing the uptake marker (ie, green fluorescence of calcein, but no red fluorescence of PI), hereafter referred to as uptake cells; non-viable cells (ie, red fluorescence of PI); and fragmented cells (ie, cells identified as "lost" based on reduced cell concentration; see Materials and Methods section). We interpret all cells in the latter three groups as having bio-effects from the laser exposure. These bio-effects followed a continuum, where uptake cells had milder bio-effects, non-viable cells experienced stronger bio-effects, and fragmented cells felt the strongest bio-effects. Cells suspended in RPMI only (ie, in the absence of FBS) without laser exposure showed no significant bio-effects ${ }^{31}$ and therefore were used as negative control to construct a cell population gate for intact and fragmented cells in the forwardscattered and side-scattered analyses (flow cytometer).

For cells suspended in RPMI without serum, exposure at the lowest laser fluence $\left(25 \mathrm{~mJ} / \mathrm{cm}^{2}\right)$ led to $30 \pm 3 \%$ of cells with uptake of calcein and $10 \pm 2 \%$ of non-viable or fragmented cells (Figure 1A). At the next higher laser 
fluence $\left(33 \mathrm{~mJ} / \mathrm{cm}^{2}\right)$, bio-effects increased, with $58 \pm 6 \%$ of cells showing calcein uptake and $20 \pm 3 \%$ of cells nonviable or fragmented (Tukey's multiple comparisons test, $p<0.0001$ for uptake, $p>0.05$ for non-viable and $p>0.05$ for fragmented). At still higher laser fluence (i.e $44 \mathrm{~mJ} /$ $\mathrm{cm}^{2}$ and above), bio-effects continued to increase, but the percentage of cells with calcein uptake decreased, while non-viable and fragmented cells increased (one-way ANOVA, $\mathrm{p}<0.0001$ for uptake, non-viable, and fragmented cells). These findings indicate that the maximum percentage of cells with calcein uptake was limited by loss of cell viability as laser-mediated bio-effects increased.

In comparison, cells suspended with FBS were able to maintain high viability even with increased laser fluence, and thereby achieved high levels of uptake (Figure 1A). Although laser exposure at the lowest fluence $\left(25 \mathrm{~mJ} / \mathrm{cm}^{2}\right)$ produced a lower percentage of cells with calcein uptake compared to cells in RPMI alone (one-way ANOVA, p < $0.0001)$, the population of cells with uptake continued to grow with increasing fluence until $55 \mathrm{~mJ} / \mathrm{cm}^{2}$ (two-way ANOVA, $\mathrm{p}<0.0001$ ), after which uptake appeared to saturate at as much as $\sim 80 \%$ of cells, with high cell viability.

For a given fluence above $25 \mathrm{~mJ} / \mathrm{cm}^{2}$, percentages of viable cells increased with increasing FBS concentration (one-way ANOVA, p $<0.05$ ) and percentages of nonviable and fragmented cells decreased with increased FBS concentration, to as little as $\sim 10 \%$ non-viable cells with essentially no fragmented cells seen at the highest FBS concentration (two-way ANOVA, $\mathrm{p}<0.0001$ for both non-viable and fragmented cells) (Figure 1A). Additionally, for $15 \%$ FBS-containing media, no

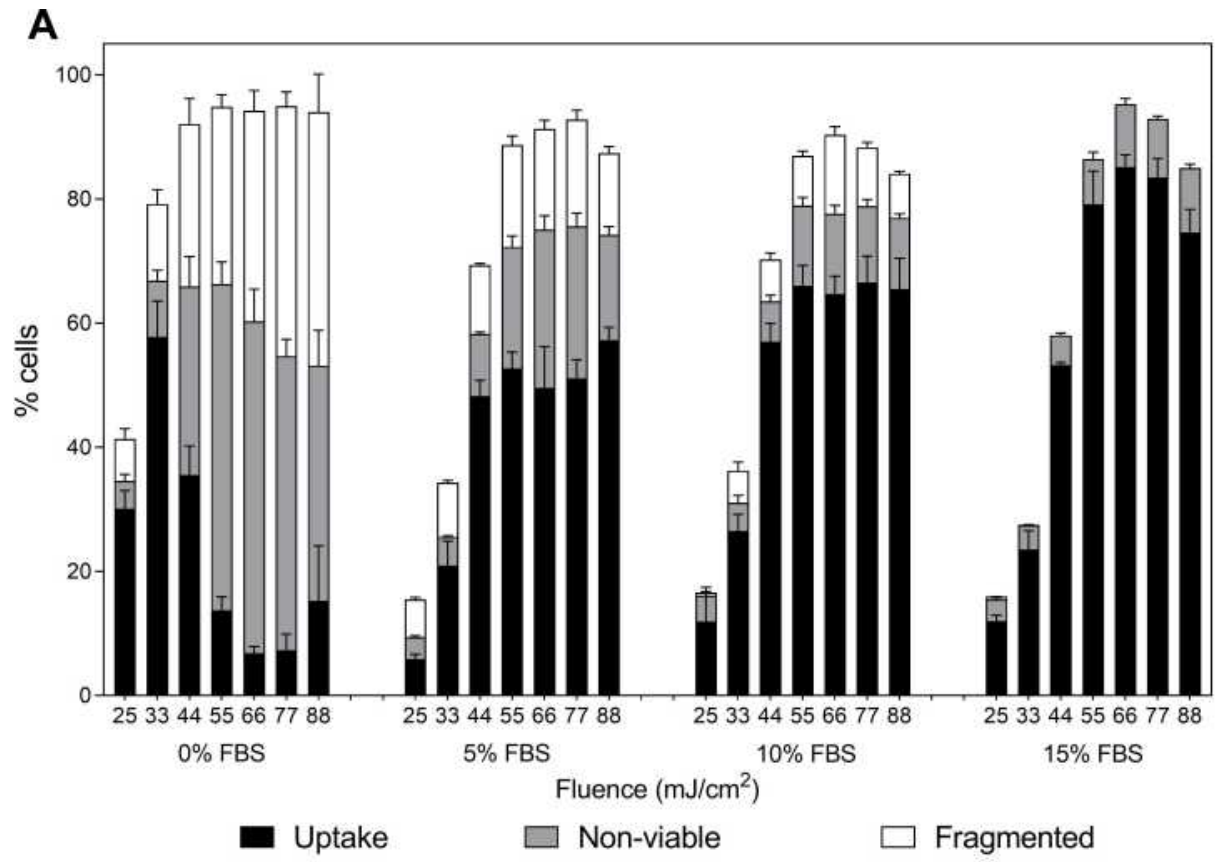

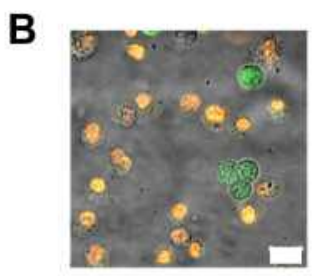

$0 \%$ FBS

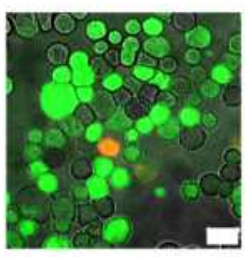

$5 \%$ FBS

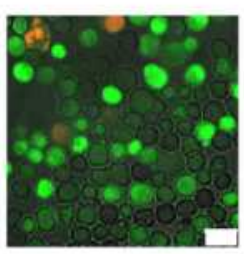

$10 \%$ FBS

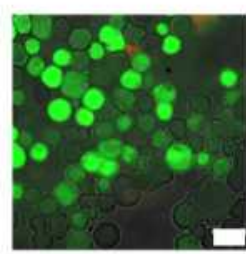

$15 \%$ FBS

Figure I Changes in bio-effects due to presence of fetal bovine serum (FBS) during photoporation of DUI45 cells. (A) Distribution of uptake cells, non-viable cells, and fragmented cells at various FBS concentrations, expressed as a volume percent of cell suspension media. The fluence in each case varied from $25 \mathrm{~mJ} / \mathrm{cm}^{2}$ to $88 \mathrm{~mJ} / \mathrm{cm}^{2}$. All samples contained $26.3 \mathrm{mg} / \mathrm{L}$ carbon black nanoparticles and $10 \mu \mathrm{M}$ calcein, and were exposed to laser pulses for I min. Data are expressed as mean \pm SEM based on 3 replicates each. (B) Representative fluorescence microscopy images of DUI45 cells exposed to laser at $55 \mathrm{~mJ} / \mathrm{cm}^{2} \mathrm{fluence}$, that were suspended in media containing varying FBS concentrations. Viable cells with molecular uptake are marked by the green fluorescence of calcein. Non-viable cells were stained by propidium iodide and exhibit orange (red and green combined) fluorescence. White scale bars at the bottom right represent $20 \mu \mathrm{m}$. Images are each representative of 3 independent samples. 
significant differences were observed in percentage of viable cells across all fluence values tested (one-way ANOVA, $p>0.05)$. Therefore, it is notable that with increasing FBS concentrations, the distribution of cells among the possible cellular outcomes shifted, so that increasing FBS concentration resulted in more viable cells with uptake and fewer non-viable or fragmented cells. Thus, the higher percentage of cells showing calcein uptake appears to be caused by the reduction of cell viability loss due to the presence of FBS during laser exposure, ie, cells that would have become non-viable without FBS maintained their viability and became uptake cells due to the protective effects of FBS.

We further found that the presence of serum in cell suspension media lowered the total bio-effects caused by photoporation at a given fluence value (two-way ANOVA, $\mathrm{p}<0.05$ for each fluence) (Figure 1A). At lower fluence, this resulted in a lower percentage of uptake, non-viable, and fragmented cells in the presence of serum (two-way ANOVA, $\mathrm{p}<0.05)$. However, when laser fluence was increased, viability loss due to photoporation decreased and the percentage of cells with calcein uptake increased in presence of serum (two-way ANOVA, $\mathrm{p}<0.05$ ). At the highest fluence values (ie, $55-88 \mathrm{~mJ} / \mathrm{cm}^{2}$ ), total bio-effects saturated at $\sim 100 \%$ and there was no effect of serum concentration on total bio-effects (one-way ANOVA, $\mathrm{p}>0.05)$.

These findings come from flow cytometry analysis and can be qualitatively corroborated with fluorescence imaging of laser irradiated cells suspended in varying FBS concentrations, as shown in Figure 1B. With the increase in FBS concentration, two things become noticeable in laser irradiated samples: the number of non-viable cells (stained with PI, seen in orange) decreased and the number of viable cells with calcein uptake (seen in green) increased with increase in FBS concentration. These trends are similar to the results generated by flow cytometry analysis in Figure 1A.

To test the generalizability of these findings, we also checked whether the cell viability protection offered by FBS could be seen in a different cell type. Human dermal fibroblast cells, suspended either in media containing no FBS or containing $15 \% \mathrm{v} / \mathrm{v}$ FBS, were exposed to laser at a fluence of $88 \mathrm{~mJ} / \mathrm{cm}^{2}$ in presence of $\mathrm{CB}$ nanoparticles and calcein. As shown in Figure 2, human dermal fibroblast cells suspended in FBS-containing media had a significantly higher percentage of viable cells with calcein uptake compared to human dermal fibroblast cells suspended in RPMI only ( $\mathrm{p}<0.05$ ). This suggested that serum's ability to provide cell viability protection during photoporation persisted in this additional cell type.

\section{Need for FBS Presence During Laser Exposure for Viability Protection}

To investigate whether presence of FBS was necessary during laser exposure to provide cell viability protection, $10 \% \mathrm{v} / \mathrm{v}$ FBS was added to the cell suspension at different times before or after laser exposure (Figure 3). We found that time of FBS addition significantly affected bio-effects (one-way ANOVA, $p<0.0001$ for uptake, non-viable, and fragmented cells). Notably, $62 \pm 1 \%$ of cells were viable and had calcein uptake when FBS was added immediately before laser exposure while only $20 \pm$ $1 \%$ cells remained viable and had calcein uptake when FBS was added immediately after laser exposure (Tukey's multiple comparison tests, $\mathrm{p}<0.0001$ ). Similarly, $23 \pm 4 \%$ cells were non-viable and $3 \pm 1 \%$ cells were fragmented when FBS was added immediately before laser exposure while $57 \pm 2 \%$ of cells were nonviable and $19 \pm 1 \%$ of cells were fragmented (Tukey's multiple comparison tests, $\mathrm{p}<0.0001$ ) when FBS was added immediately after laser exposure. These data indicate that presence of FBS during laser exposure (ie, during photoporation) was important for viability protection.

The extent of viability protection offered by FBS when added immediately before laser exposure was not significantly different from the case where FBS was originally present in cell suspension media well before laser exposures (Tukey's multiple comparison test, $\mathrm{p}>0.05$ for both non-viable and fragmented cells). However, it is notable that FBS addition immediately after laser exposure offered some viability protection compared to the laser exposure protocol without FBS at all, since a higher percentage of cells had uptake (Tukey's multiple comparison tests, $\mathrm{p}<$ 0.0001 ) and a lower percentage of cells were fragmented (Tukey's multiple comparison tests, $\mathrm{p}<0.0001$ ) compared to the no-FBS case.

\section{FBS Components Responsible for Viability Protection}

To identify the FBS components responsible for protecting cell viability during photoporation, FBS was sizefiltered using membranes with $5 \mathrm{kDa}$ or $30 \mathrm{kDa}$ molecular weight cutoffs. Figure 4 shows that bio-effects depended 


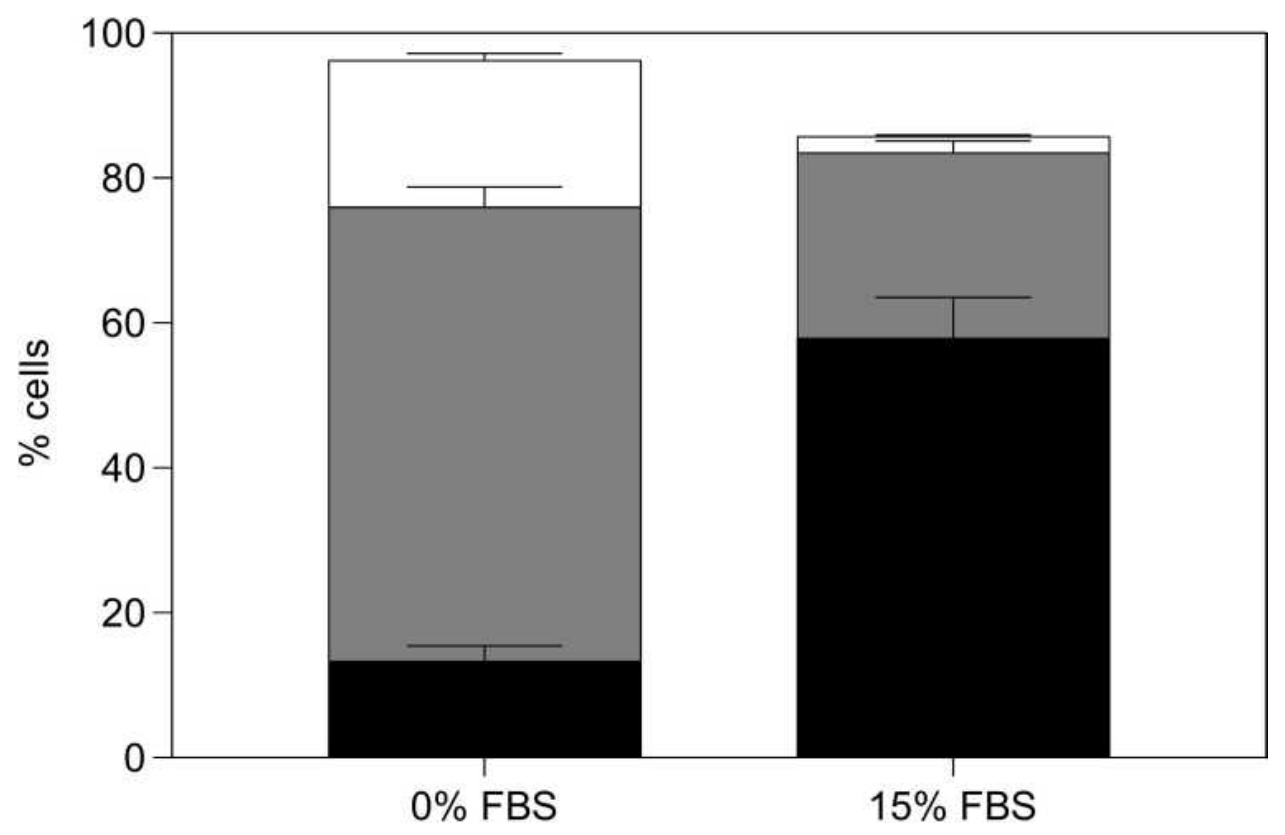

Cell suspension media

Uptake $\rightleftharpoons$ Non-viable $\square$ Fragmented

Figure 2 Changes in bio-effects due to presence of fetal bovine serum (FBS) during photoporation of human dermal fibroblast cells. Distribution of uptake cells, non-viable cells, and fragmented cells at $0 \%$ and I5\% v/v FBS. Laser exposure was carried out at a fluence of $88 \mathrm{~mJ} / \mathrm{cm}^{2}$ for I min. All samples contained $26.3 \mathrm{mg} / \mathrm{L}$ carbon black nanoparticles and $10 \mu \mathrm{M}$ calcein. Data are expressed as mean \pm SEM based on 3 replicates each.

on molecular weight of the FBS components in cell suspension media (one-way ANOVA, $\mathrm{p}<0.0001$ for uptake, non-viable, and fragmented cells). However, we saw no significant differences between cells suspended in unaltered FBS (without the molecular size cutoff), FBS containing only compounds above a $5 \mathrm{kDa}$ cutoff, and FBS containing compounds only above $30 \mathrm{kDa}$ cutoff (Tukey's multiple comparisons test, $\mathrm{p}>0.05$ ). Additionally, no significant differences were seen between cells suspended without FBS, FBS containing only compounds below a $5 \mathrm{kDa}$ cutoff, and FBS containing compounds only below $30 \mathrm{kDa}$ cutoff (Tukey's multiple comparisons test, $\mathrm{p}>0.05)$. Bio-effects from these conditions were all significantly different from bio-effects seen in three conditions with the high molecular weight FBS components (Tukey's multiple comparisons test, $\mathrm{p}<0.05)$.

Because only components of FBS greater than $30 \mathrm{kDa}$ were needed to enable high uptake with high cell viability, we hypothesized that laser irradiation in the presence of albumin, which is the most abundant protein in serum and has a molecular weight of $66 \mathrm{kDa}$, would be as effective as full FBS. Because $10 \% \mathrm{v} / \mathrm{v}$ FBS contains $0.2 \% \mathrm{w} / \mathrm{v}$ albumin and $0.6 \% \mathrm{w} / \mathrm{v}$ total protein, ${ }^{32}$ we exposed cells to laser irradiation in the presence of $0.2 \% \mathrm{w} / \mathrm{v}$ and $0.6 \% \mathrm{w} / \mathrm{v}$ BSA, as well as $1 \% \mathrm{w} / \mathrm{v} \mathrm{BSA}$ to further assess concentration dependence.

We found that increasing BSA concentration led to an increase in percentage of cells with calcein uptake (oneway ANOVA, $p<0.0001)$ and caused decrease in nonviable and fragmented cells (one-way ANOVA, p < 0.0001 ), as seen in Figure 5A. While $81 \pm 4 \%$ of cells lost viability (non-viable and fragmented combined) when cells were exposed to laser without added protein, only 53 $\pm 2 \%$ of cells lost viability when they were suspended in $0.2 \%$ BSA ( $p<0.0001), 39 \pm 4 \%$ of cells lost viability when suspended in $0.6 \%$ BSA $(p<0.0001)$, and $31 \pm 1 \%$ of cells lost viability when suspended in $1 \%$ BSA $(p<$ 0.0001). These data show that serum albumin alone was able to offer viability protection similar to full FBS, where effectiveness increased with greater albumin concentration.

To evaluate whether BSA is specifically needed or if other proteins could also offer similar protection, we exposed cells to laser irradiation in the presence of varying concentrations of hemoglobin. As shown in Figure 5B, adding hemoglobin during laser exposure resulted in significantly higher percentages of cells with calcein uptake compared to cells suspended in RPMI only (one-way 

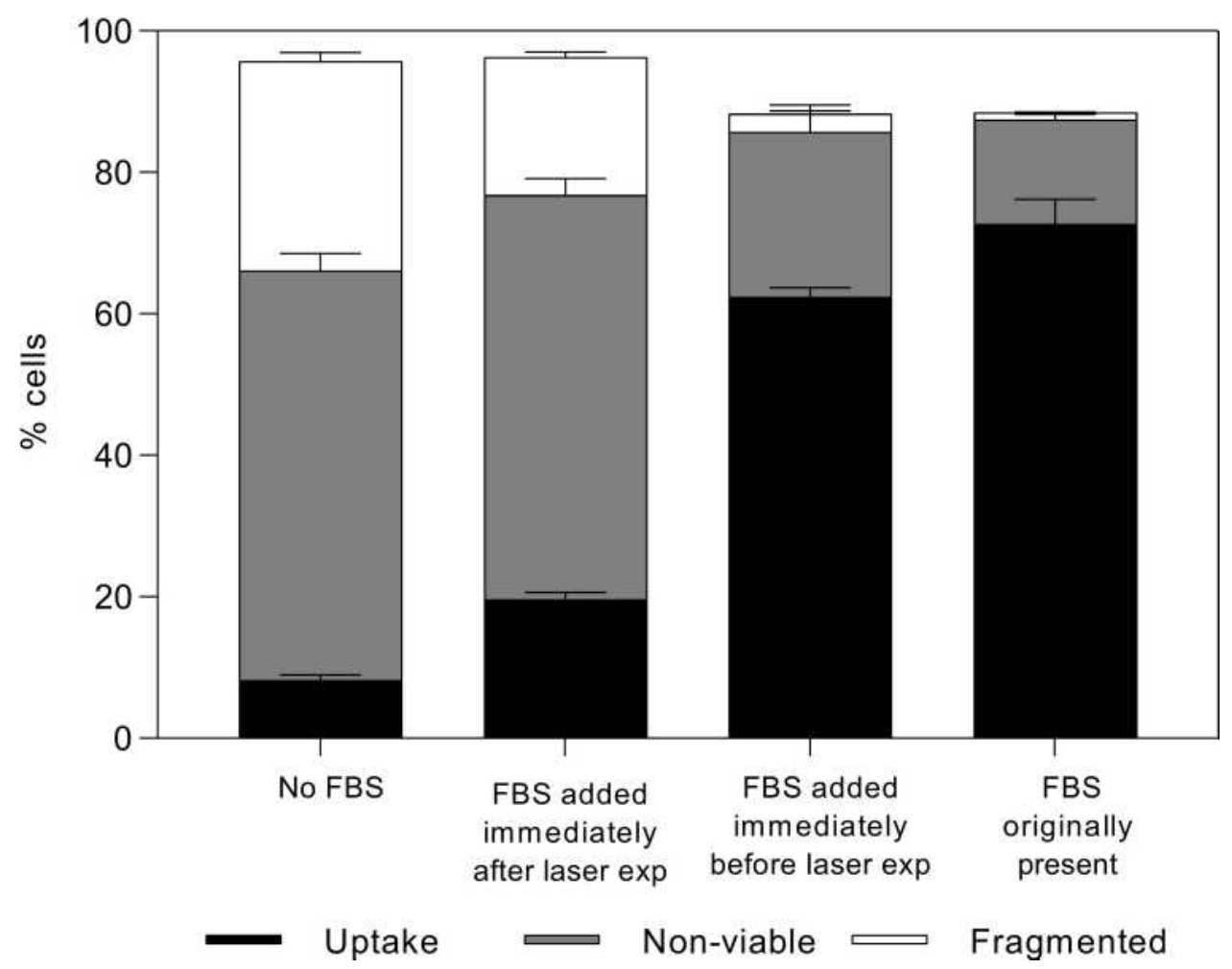

Figure 3 Changes in bio-effects due to addition of serum (FBS) at different times before and after photoporation of DUI45 cells. Distribution of uptake cells, non-viable cells, and fragmented cells with $10 \% \mathrm{v} / \mathrm{v}$ FBS added at the beginning of the experiment ( $>60$ min before laser), immediately before ( $<10 \mathrm{~s})$ laser exposure, or immediately after (<10 s) laser exposure. Laser exposure was carried out at a fluence of $88 \mathrm{~mJ} / \mathrm{cm}^{2}$ for I min. All samples contained $26.3 \mathrm{mg} / \mathrm{L}$ carbon black nanoparticles and $10 \mu \mathrm{M}$ calcein. Data are expressed as mean \pm SEM based on 3 replicates each.
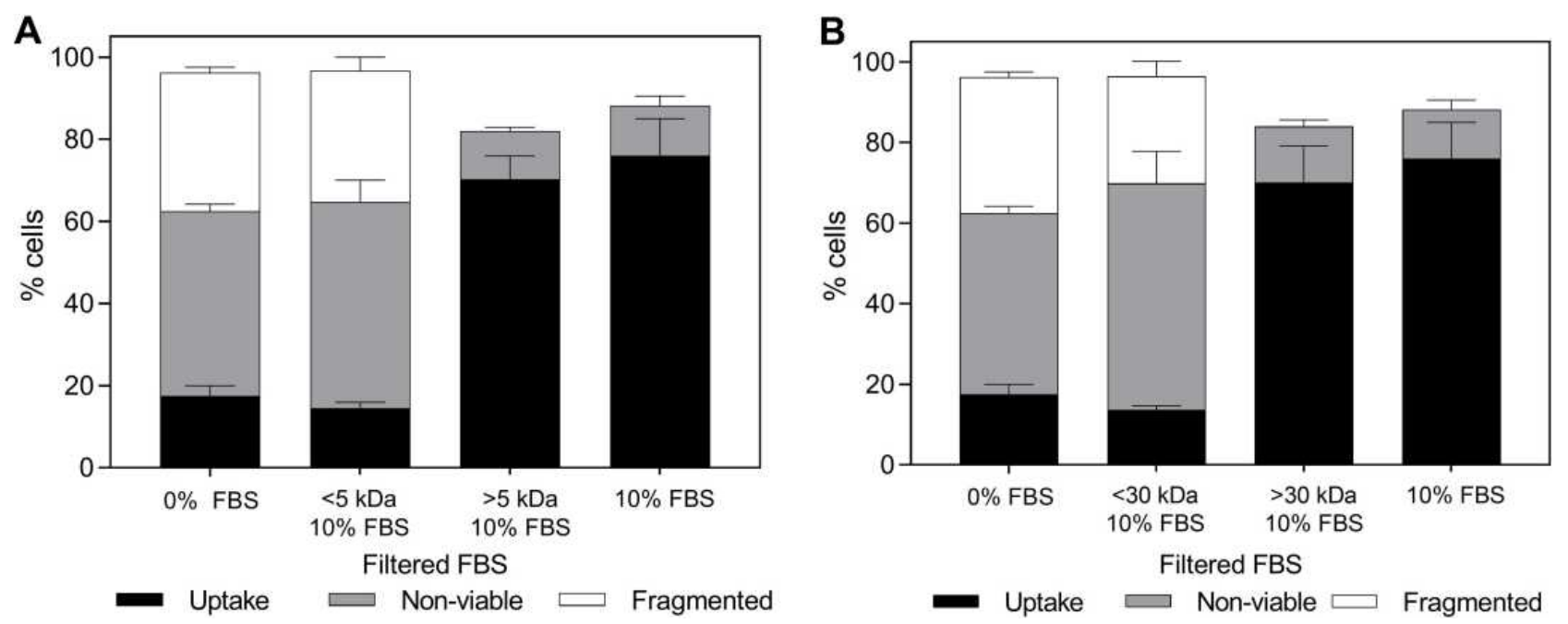

Figure 4 Changes in bio-effects due to the presence of filtered fetal bovine serum (FBS) with different molecular weight cutoffs during photoporation of DUI45 cells. Distribution of uptake cells, non-viable cells, and fragmented cells with 10\% v/v FBS without alteration, with fractions above or below a (A) $5 \mathrm{kDa}$ or (B) $30 \mathrm{kDa}$ molecular weight cut off. Laser exposure was carried out at a fluence of $55 \mathrm{~mJ} / \mathrm{cm}^{2}$ for I min. All samples contained $26.3 \mathrm{mg} / \mathrm{L}$ carbon black nanoparticles and $10 \mu \mathrm{M}$ calcein. Data are expressed as mean \pm SEM based on 3 replicates each.

ANOVA, $\mathrm{p}<0.0001)$. The uptake and non-viable cell percentage did not significantly vary with increasing hemoglobin concentrations (one-way ANOVA, $\mathrm{p}>0.05$ for both uptake and non-viable cells). However, the percentage of fragmented cells decreased with increasing hemoglobin concentrations (one-way ANOVA, $\mathrm{p}<0.001$ ). Altogether, these data suggest that the viability protection caused by FBS may be generally associated with proteins in FBS, and that other 


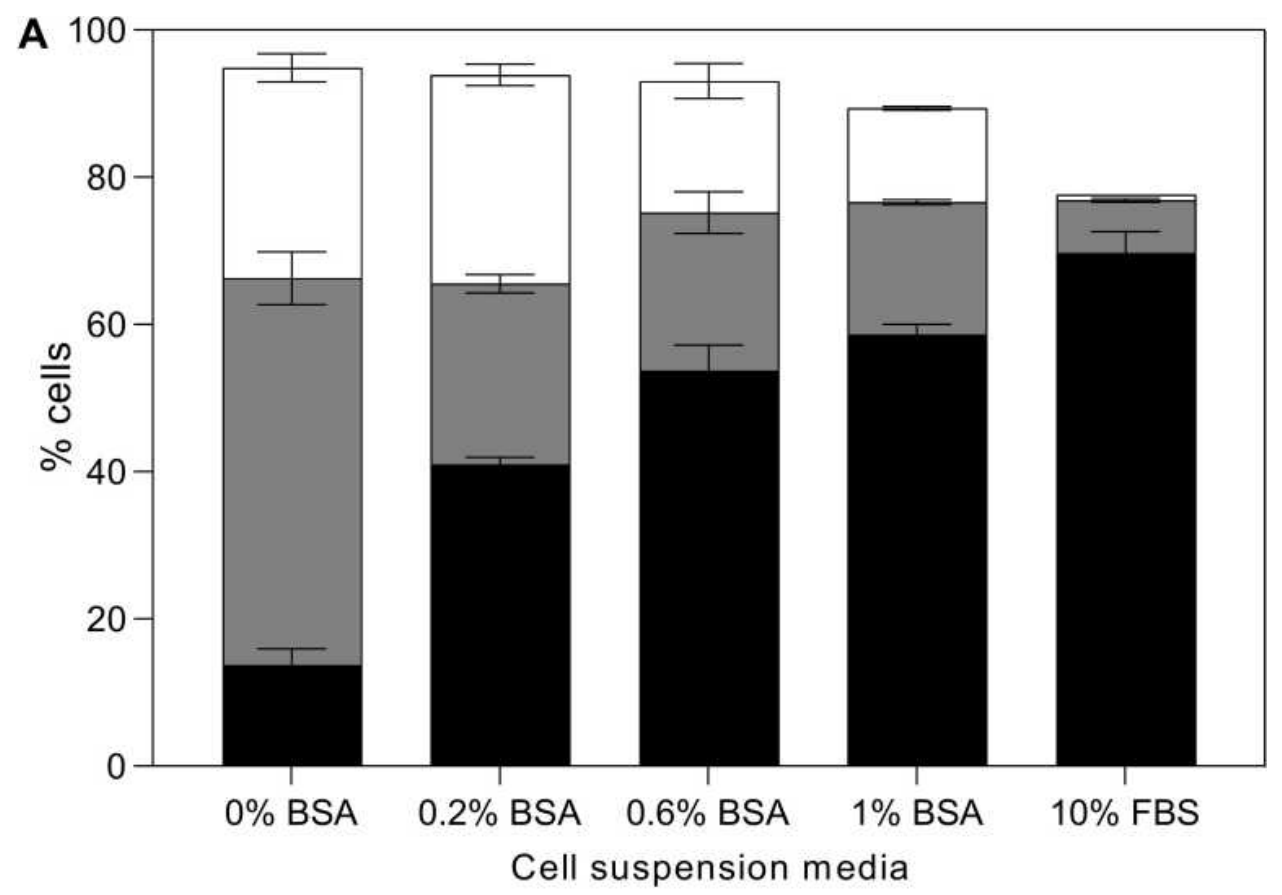

Uptake $\sqsubset$ Non-viable $\longleftarrow$ Fragmented

B

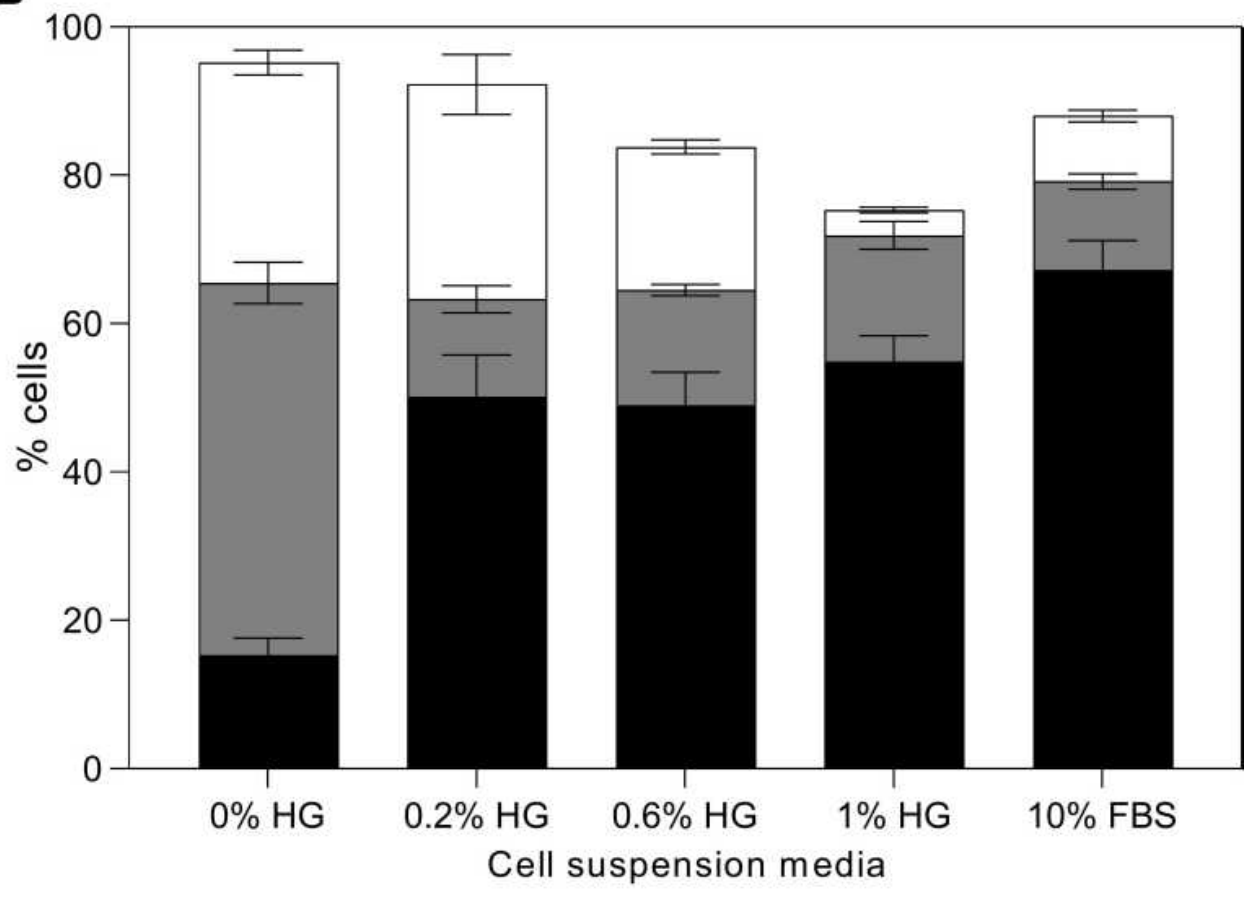

Uptake Non-viable

Fragmented

Figure 5 Changes in bio-effects due to the presence of protein during DUI45 cell photoporation. Distribution of uptake cells, non-viable cells, and fragmented cells with $0.2 \% \mathrm{w} / \mathrm{v}, 0.6 \% \mathrm{w} / \mathrm{v}$ or $1 \% \mathrm{w} / \mathrm{v}(\mathbf{A})$ bovine serum albumin or $(\mathbf{B})$ hemoglobin. Laser exposure was carried out at a fluence of $55 \mathrm{~mJ} / \mathrm{cm}^{2}$ for I min. All samples contained $26.3 \mathrm{mg} / \mathrm{L}$ carbon black nanoparticles and $10 \mu \mathrm{M}$ calcein. Data are expressed as mean \pm SEM based on 3 replicates each. 
proteins including BSA and hemoglobin can be similarly protective.

\section{Need for FBS Protein Biological Activity}

To investigate whether the protective effects of serum are associated with protein biological activity, we conducted photoporation experiments with FBS proteins denatured through either heat or sonication. Bio-effects plotted in Figure 6A suggest that addition of denatured FBS proteins was able to significantly protect cells compared to RPMI only (one-way ANOVA, $\mathrm{p}<0.0001$ for uptake, non-viable, and fragmented cells). Additionally, no significant differences in bio-effects were seen among the two denatured FBS suspensions or compared to full FBS suspension (oneway ANOVA, $\mathrm{p}>0.05$ for uptake, non-viable, and fragmented cells). These results show that serum protein biological activity did not appear to be needed to provide similar viability protection as full, biologically active FBS.

\section{Role of Viscosity}

If protein biological activity was not needed, perhaps the increased viscosity of FBS played a role. To check this, we added $0.1 \%$ carboxyl methylcellulose (CMC) in RPMI to match the viscosity of $10 \%$ FBS media (ie, $1.28 \pm 0.14$ $\mathrm{cP})$. However, bio-effects after laser exposure in the viscous RPMI were not significantly different compared to RPMI with $1 \mathrm{cP}$ viscosity (Tukey's multiple comparison tests, $\mathrm{p}>0.05$ for uptake, non-viable, and fragmented cells) and resulted in significantly less uptake (Tukey's multiple comparison tests, $\mathrm{p}<0.0001$ ) and more viability loss (Tukey's multiple comparison tests, $\mathrm{p}<0.0001$ ) compared to laser exposure in FBS (Figure 6B).

\section{Viability Protection Offered by Polymers}

We next wondered if proteins were critical to the protective effects of serum, or if synthetic polymers could work equally well. To evaluate the effects of synthetic polymers on photoporation, cells were suspended in media containing up to $1 \%$ $\mathrm{w} / \mathrm{v}$ concentrations of five different polymers in RPMI. These were chosen as a representative set of polymers based on their prior usage in literature for cell viability protection against mechanical damage, by modifying the suspension media and cell membrane properties. ${ }^{33-36}$ Data in Figure 7 show that upon adding PHPMA (47500 Da), percentages of uptake cells, non-viable cells, and fragmented cells were not significantly different compared to samples with only RPMI (oneway ANOVA, $p>0.05)$. Adding PEG (10000 Da) increased the percentage of uptake cells (one-way ANOVA, $\mathrm{p}<0.01$ ) and decreased the percentage of non-viable cells (one-way ANOVA, $\mathrm{p}<0.01$ ) with increasing PEG concentration. However, even at the highest PEG concentration $(1 \% \mathrm{w} / \mathrm{v})$, uptake was lower (Tukey's multiple comparison tests, $\mathrm{p}<$ 0.0001 ) and viability loss was higher compared to $10 \%$ FBS (Tukey's multiple comparison tests, $\mathrm{p}<0.001$ ).

Laser exposure with PVP (25000 Da), PEOX (50000 Da), or Pluronic F127 exhibited increased percentages of

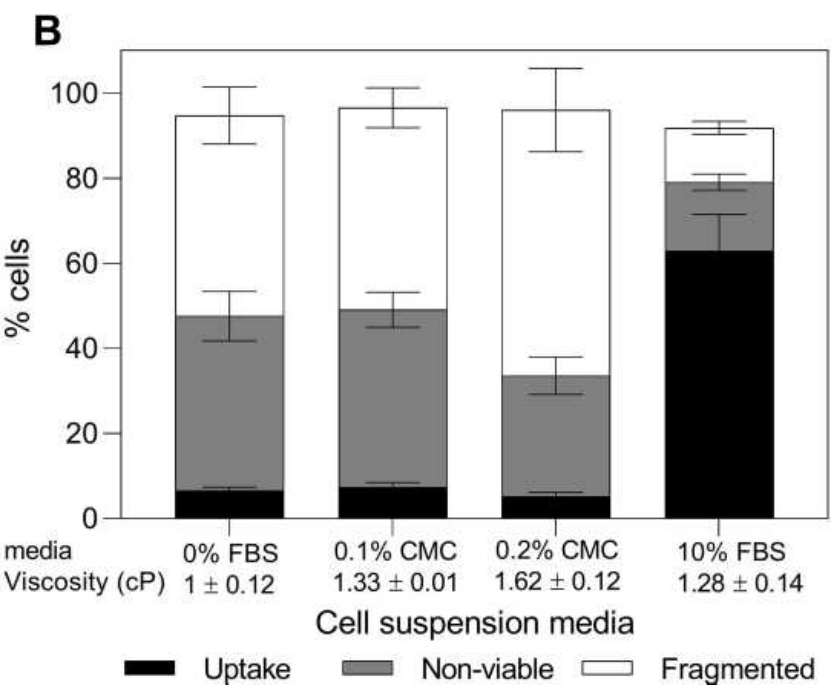

Figure 6 Changes in bio-effects due to the presence of denatured bovine serum albumin or carboxymethylcellulose (CMC) during DUI45 cell photoporation. Distribution of uptake cells, non-viable cells and fragmented cells with (A) fetal bovine serum (FBS) denatured by sonication or heat or (B) with CMC added to match or exceed the viscosity of $10 \% \mathrm{v} / \mathrm{v}$ FBS. Laser exposure was carried out at a fluence of $88 \mathrm{~mJ} / \mathrm{cm}^{2}$ for I min. All samples contained $26.3 \mathrm{mg} / \mathrm{L}$ carbon black nanoparticles and $10 \mu \mathrm{M}$ calcein. Viscosity was measured using a viscometer at $25^{\circ} \mathrm{C}$ (Brookfield DV2T, Brookfield AMETEK, Middleboro, MA). Data are expressed as mean \pm SEM based on $\geq 3$ replicates each. 


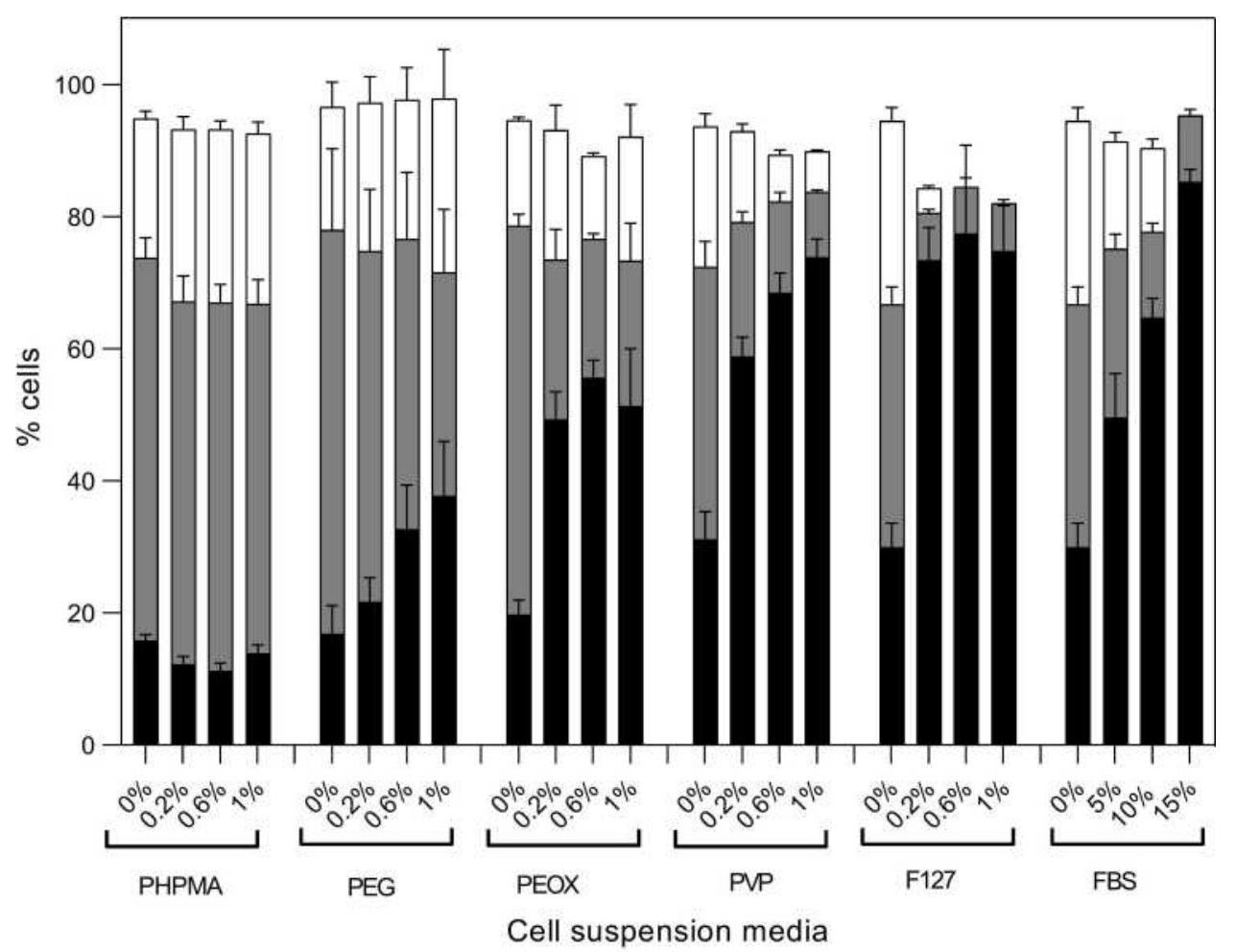

Uptake

Non-viable

Fragmented

Figure 7 Changes in bio-effects due to the presence of synthetic polymers during DUI45 cell photoporation. Distribution of uptake cells, non-viable cells and fragmented cells with polyethylene glycol (PEG), poly(N-(2-hydroxypropyl) methacrylamide) (PHPMA), polyvinylpyrrolidone (PVP), poly(2-ethyl-2-oxazoline) (PEOX), or Pluronic FI27 polymers at different concentrations (w/v) compared to fetal bovine serum (FBS) at different concentrations ( $\mathrm{v} / \mathrm{v}$ ). Laser exposure was carried out at a fluence of $55 \mathrm{~mJ} / \mathrm{cm}^{2}$ for I min. All samples contained $26.3 \mathrm{mg} / \mathrm{L}$ carbon black nanoparticles and $10 \mu \mathrm{M}$ calcein. Data are expressed as mean \pm SEM based on 3 replicates each.

cells with uptake (Tukey's multiple comparisons test, $\mathrm{p}<$ $0.0001)$ and decreased loss of viability (Tukey's multiple comparisons test, $\mathrm{p}<0.001$ ) compared to exposure with RPMI alone, which is consistent with prior results using Pluronics. ${ }^{37}$ Only PVP showed a dependence of percentage of cells with uptake (one-way ANOVA, $p<0.0001$ ) and viability loss (one-way ANOVA, $\mathrm{p}<0.001$ ) with increasing polymer concentration. All three polymers achieved uptake levels that were similar to (Tukey's multiple comparisons test, $\mathrm{p}>0.05$ for PEOX) or greater than $5 \%$ FBS (Tukey's multiple comparisons test, $\mathrm{p}<0.05$ for PVP and Pluronic F127), and in some cases (ie, PVP, Pluronic F127) comparable to $10 \%$ or $15 \%$ FBS (Tukey's multiple comparisons test, $\mathrm{p}>0.05$ for $0.6 \%$ and $1 \%$ PVP and Pluronic F127). We conclude that synthetic polymers were able to provide enhanced cell viability protection compared to RPMI during photoporation, although not all polymers performed equally well.

Polymers such as PEG, PVP and Pluronics have previously been shown to offer viability protection against fluid-mechanical damage in bioreactors, ${ }^{33}$ allow faster cell growth, ${ }^{38}$ and support cell wound healing as a trauma therapeutic. ${ }^{37,39}$ Thus, the above results, in addition to literature findings, support the use of synthetic polymers for viability protection in wide variety of applications. Fluorescence intensity plots (Supplementary Information - Figure S1) also show that the presence of viability protection additive ( $10 \% \mathrm{FBS})$ does not affect the amount of calcein delivered due to photoporation.

\section{Polymer Properties Governing Viability Protection Performance}

The polymers used in this study were chosen as a representative set of compounds that are non-toxic to cells and shown in prior studies to protect cells during mechanical insult. ${ }^{33-36}$ However, these polymers have varying properties and their ability to protect cell viability also varied, as shown in Figure 7. We hypothesized that the physical interactions between polymers (and proteins) and the cell membrane were responsible for viability protection, since intracellular uptake, as well as loss of cell viability, are believed to be caused during photoporation via creation of 

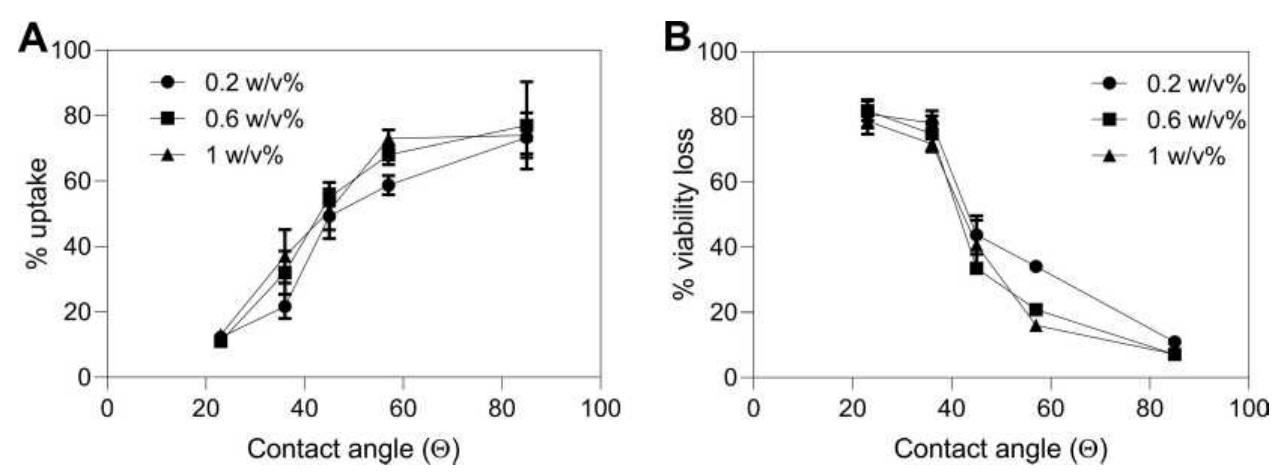

Figure 8 Changes in bio-effects as a function of contact angle of polymers present during DUI45 photoporation. Percentage of $(\mathbf{A})$ uptake cells and (B) non-viable + fragmented cells with different polymer having different contact angles: $23^{\circ}$ for poly ( $\mathrm{N}$-(2-hydroxypropyl) methacrylamide) (PHPMA); $36^{\circ}$ for polyethylene glycol (PEG); $45^{\circ}$ for poly(2-ethyl-2-oxazoline) (PEOX); $57^{\circ}$ for polyvinylpyrrolidone (PVP); and $85^{\circ}$ for Pluronic FI27..$^{4-49}$ The bio-effects data are from Figure 7. Laser exposure was carried out at a fluence of $55 \mathrm{~mJ} / \mathrm{cm}^{2}$ for I min. All samples contained $26.3 \mathrm{mg} / \mathrm{L}$ carbon black nanoparticles and $10 \mu \mathrm{M}$ calcein. Data are expressed as mean \pm SEM based on 3 replicates each.

transient pores in the cell membrane. Given that creation of aqueous pores across the cell membrane requires creation of a hydrophilic pathway across the hydrophobic core of the lipid bilayer cell membrane, ${ }^{40}$ we explored the possibility that hydrophobic interactions between the polymer and the cell membrane were the dominant force in accelerated cell repair and cell viability protection.

We characterized polymer hydrophobicity on the basis of contact angle of water. Figure 8 shows bio-effects plotted against contact angle of each of the polymers used. We found that for each polymer at each polymer concentration, the percentage of uptake cells increased (one-way ANOVA, $\mathrm{p}<0.0001$ ) (Figure 8A) and the percentage of non-viable cells decreased (one-way ANOVA, $\mathrm{p}<0.0001$ ) (Figure 8B) with increasing polymer contact angle (ie, increasing polymer hydrophobicity). This correlation is consistent with our hypothesis that hydrophobic interactions are important to the protective effect of polymers on cells during photoporation and with prior studies examining the role of surface tension in bubble-mediated cell damage. ${ }^{41}$

We also studied the effect of polymer molecular weight by adding $10 \mathrm{kDa}-600 \mathrm{kDa}$ PEG, as well as $10 \mathrm{kDa}-360$ $\mathrm{kDa} P V P$, in cell suspension media during photoporation, to examine the effects of polymer molecular weight on viability protection. We found that increasing molecular weight increased percentages of viable cells with calcein uptake (one-way ANOVA, p < 0.0001) (Figure 9A) while it decreased percentages of non-viable and fragmented cells (one-way ANOVA, $p<0.0001$ ) (Figure 9B). For cells suspended in $10 \mathrm{kDa}$ PEG, $21 \pm 2 \%$ were uptake cells while $70 \pm 5 \%$ cells lost viability. In comparison, cells suspended in $600 \mathrm{kDa}$ PEG behaved dramatically differently, with $63 \pm 4 \%$ of cells showing uptake (Tukey's multiple comparisons test, p < 0.0001) while 29 $\pm 2 \%$ of cells lost viability (Tukey's multiple comparisons test, $\mathrm{p}<0.0001)$.
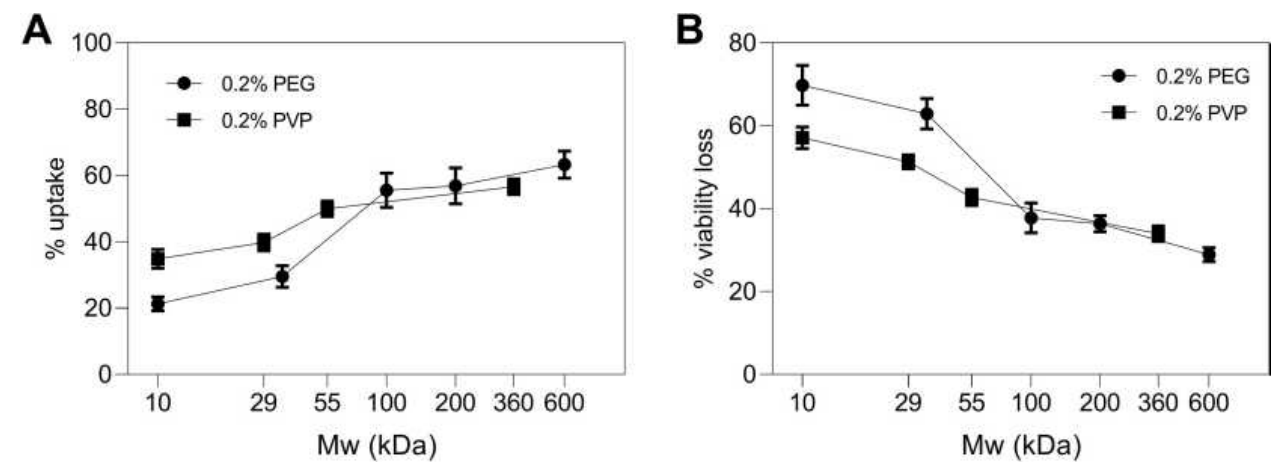

Figure 9 Changes in bio-effects as a function of molecular weight of polymers present during DUI45 photoporation. Percentage of (A) uptake cells and (B) non-viable + fragmented cells with different polymers present at a concentration of $0.2 \mathrm{w} / \mathrm{v} \%$, having different molecular weight: $10 \mathrm{kDa}, 35 \mathrm{kDa}, 100 \mathrm{kDa}, 200 \mathrm{kDa}$, and $600 \mathrm{kDa}$ polyethylene glycol (PEG); and $10 \mathrm{kDa}, 29 \mathrm{kDa}, 55 \mathrm{kDa}$ and $360 \mathrm{kDa}$ polyvinylpyrrolidone (PVP). Laser exposure was carried out at a fluence of $55 \mathrm{~mJ} / \mathrm{cm}^{2}$ for I min. All samples contained $26.3 \mathrm{mg} / \mathrm{L}$ carbon nanoparticles and $10 \mu \mathrm{M}$ calcein. Data are expressed as mean \pm SEM based on 3 replicates each. 
These results suggest that PEG molecular weight plays an important role in determining its ability to provide viability protection during photoporation. A similar trend was observed for varying molecular weights of PVP present in cell suspension media during photoporation (Figure 9 ). The data show that with increasing molecular weight of PVP in cell suspension media, the percentage of viable cells with calcein uptake increased (one-way ANOVA, $\mathrm{p}<$ 0.0001) (Figure 9A), while percentages of non-viable and fragmented cells, represented as viability loss, decreased (one-way ANOVA, $\mathrm{p}<0.05$ ) (Figure 9B). Hence, the viability protection ability of both polymer additives appears to be dependent on their molecular weights.

\section{Discussion}

\section{Protective Effects of FBS}

In this study, we explored the effects of FBS addition to cell suspension media during nanoparticle-mediated photoporation for fluorescent calcein delivery into DU145 cells. Photoporation can cause three different bioeffects examined in this study: uptake of calcein into viable cells (uptake cells), viability loss due to photoporation of intact cells (non-viable cells), and viability loss due to fragmentation (fragmented cells). When cells were exposed to high laser fluence during photoporation, significant viability loss occurred due to cell death and fragmentation. Data in Figure 1 showed that lower fluence caused less viability loss, but viability loss then increased at higher laser fluence levels. Similar results have previously been observed in studies aimed at understanding the effects of changing photoporation parameters. ${ }^{18,42}$

However, when FBS was present in the cell suspension media during photoporation, total viability loss became lower at high fluence, which resulted in a higher percentage of cells with calcein uptake, compared to photoporation with no FBS. Although this was true for all three concentrations of FBS tested in the current study, higher FBS concentrations resulted in greater viability protection. Previous studies had shown no difference between the effects of photoporation on uptake or viability by adding CB nanoparticles immediately before laser exposure or adding the $\mathrm{CB}$ nanoparticles many hours earlier. ${ }^{14}$ This indicates that the FBS' ability to change bio-effects should be unrelated to endocytosis of CB nanoparticles by cells. Other studies examining damaging effects of agitated and aerated bioreactors showed FBS concentration-dependent viability protection and faster growth of mammalian cells. ${ }^{23,34}$ In these studies, however, FBS was added to protect cells against fluid-mechanical damage caused by shear and bubble breakup. Therefore, the mechanism for viability protection could be different than in photoporation. We also found that FBS can protect viability of human dermal fibroblasts during photoporation and thus, this feature is not exclusive to a single cell type. We further showed that FBS must be present in cell suspension media when cells are exposed to laser pulses and pores are formed to provide viability protection. This observation suggests that the presence of FBS is needed during cell membrane pore formation, or immediately thereafter, to lower viability loss.

\section{Protective Effects of Proteins}

FBS contains many proteins, hormones, enzymes, electrolytes, carbohydrates, and other compounds that vary in concentration and size. ${ }^{32}$ To check for the components that might provide viability protection, we size-filtered the FBS before adding it into cell suspension media. Photoporation experiments showed that components greater than $30 \mathrm{kDa}$ in size showed similar viability protection as seen in full FBS-containing media. We hypothesized that the albumin $(66 \mathrm{kDa})$ and other proteins present in FBS were responsible for viability protection. Data collected from experiments done with BSA in cell suspension media during photoporation were consistent with this hypothesis. Moreover, we discovered that viability protection ability was not exclusive to BSA proteins: hemoglobin proteins also protected cell viability during photoporation.

Albumin has been shown to have favorable biochemical interactions with cell membranes, thereby increasing drug delivery efficiency, in prior studies. ${ }^{43}$ Our studies also show increased delivery efficiency due to FBS and BSA addition, but these increments were caused by decreases in viability loss. However, comparable delivery enhancement and viability protection were seen, even when FBS proteins were denatured using heat and sonication. Denaturing proteins should dampen their biological activity and thus reduce the bio-chemical interactions between protein molecules and cell membrane during pore formation. Therefore, our results suggest that viability protection offered by FBS might be caused by physical interactions between FBS protein and cells. A physical mechanism was reported to be the reason behind cell viability protection caused by serum addition in bioreactors. ${ }^{24}$ This protection was shown to be caused 
by changes in cell suspension media properties such as viscosity. ${ }^{44,45}$ However, increasing cell suspension media viscosity by adding CMC failed to improve cell viability or calcein uptake in our studies. CMC was added to mimic the viscosity of representative cell suspension media that had shown viability protection. As presented in Figures 6, $0.1 \% \mathrm{CMC}$ had a viscosity measurement of $1.33 \pm 0.01 \mathrm{cP}$ which is similar to that of $10 \%$ FBS containing media $(1.28 \pm 0.14 \mathrm{cP})$. Therefore, the failure of $0.1 \% \mathrm{CMC}$ to match the viability protection provided by $10 \%$ FBS, suggests that viscosity changes brought by FBS addition in cell suspension media during photoporation, had little to no role to play in improving percent cell viability or intracellular uptake.

\section{Protective Effects of Polymers}

Following our observation that viability protection offered by FBS during photoporation might be due to physical interaction between FBS proteins and cells, we explored if this behavior could also be seen with polymer additives. We chose neutral and water-soluble polymers, some of which had already been used in cell culture bioreactors, as viability protection additives. Of the five polymers investigated, PEG, PVP, PEOX, and Pluronic F127 showed greater viability protection during photoporation than PHPMA. However, the extent of viability protection was observed to be different for different polymers. For example, the addition of $0.6 \mathrm{w} / \mathrm{v} \%$ polymer in cell suspension media led to intracellular delivery levels of $33 \pm 7 \%$ for PEG, $56 \pm 3 \%$ for PEOX, $69 \pm 3 \%$ for PVP, and $77 \pm$ $13 \%$ for Pluronic F127.

Several factors could be responsible for this variation in viability protection. When cell membranes are porated, hydrophobic parts of the lipid bilayer can be exposed, introducing thermodynamic and biological instability. ${ }^{39}$ We hypothesized that polymers that have hydrophobic components can favorably associate with exposed hydrophobic lipid parts and help in accelerated resealing of the pore opening. Surface wettability studies, such as water contact angle, have commonly been used to determine the polymeric characteristics. ${ }^{46,47}$ Hence, we used water contact angle as a measure of hydrophobicity and found that percentages of uptake cells increased with increasing contact angle and percentages of viability loss decreased. Polymers with higher contact angles had higher hydrophobicity, supporting the above hypothesis. It is important to note that all these polymers are considered hydrophilic since they are water soluble. However, each of these polymers can act as amphiphilic with both hydrophilic and hydrophobic components present in the molecular structure. Therefore, an increase in contact angle of water droplet on polymer substrate indicates an increase in the hydrophobic characteristics of the polymer. ${ }^{46-49}$

Pluronics have been studied previously as cell viability protectants and were proposed to change medium properties, such as surface tension, and enhance cell membrane resealing after exposure to external stress. . $^{37,41,50,51}$ Pluronic F127 is a triblock, non-ionic surfactant with a hydrophobic polypropylene glycol domain bound to hydrophilic PEG chains on each side. This amphiphilic feature allows Pluronic F127 to associate with exposed hydrophobic parts of porated cell membranes and lowers the risk of downstream damages to ionic balances and subcellular components. ${ }^{39}$ The significance of the amphiphilic nature of Pluronic F127 comes from a comparison with PEG (ie, one of the two components of the Pluronic F127 block co-polymer) that demonstrated the much superior ability of Pluronic F127 to protect cell viability compared to PEG. A similar analysis based on a balance of hydrophilic and hydrophobic properties can be made for PEOX and PVP, as well as BSA and hemoglobin, although without neat separation between hydrophilic and hydrophobic parts in a block copolymer structure. For these polymers, a close relative could be polysoaps that have repeating units of intrinsic amphiphilic monomers and therefore may be additional candidates for viability protection. $^{52}$

We also found that increasing molecular weight of polymers (ie, PVP and PEG) enhanced their effectiveness at protecting cells. We note that increasing molecular weight increases the hydrodynamic radius of polymers. For example, PEG's hydrodynamic radius varies from $2.8 \mathrm{~nm}$ for $10 \mathrm{kDa}$ to $29.9 \mathrm{~nm}$ for $600 \mathrm{kDa}^{53}$ Given the larger size of higher molecular weight polymers, they should find more sites to associate with the cell membrane, thereby increasing the strength of interaction by polyvalence; such molecules might more readily span and thereby seal the cell membrane pore opening.

In previous studies, polymers have been used as cell growth accelerators ${ }^{38}$ and proliferators. ${ }^{54}$ In addition, they have been used as membrane sealants to aid in repair and regeneration of damaged cell membranes. ${ }^{39,55}$ PEG, PVP, and Pluronic F127 have been studied along with FBS and BSA for almost all these applications. ${ }^{56}$ However, the exact mechanism of viability protection for each of these additives may be dependent on the molecules used, and are 
still under investigation. ${ }^{33,43,45}$ Our data show that favorable hydrophobic interactions of polymeric viability protection additives enhance the cell's ability to recover from membrane poration by either directly sealing the membrane pores or indirectly assisting the repair process, which is consistent with the hypothesis proposed in several relevant studies. ${ }^{39,55,57}$

\section{Mechanistic Considerations}

We have proposed that the effects of serum, proteins and polymers during photoporation are due to interactions of these materials with cells, but there are other possible explanations: they could affect (i) the liquid medium, thereby altering laser propagation to the nanoparticles or energy propagation from the nanoparticles to the cells, (ii) the nanoparticles and the way in which they absorb and release energy and (iii) the cells and their response to photoporation. It is unlikely that propagation of the laser beam through the medium was significantly affected by addition of these soluble compounds at low concentration that should not significantly absorb the near-infrared light. Likewise, we do not expect energy transduction - whether thermal or acoustic - through the medium would be meaningfully affected, as heat capacity, thermal conductivity, viscosity and other properties should have little or no significant changes by these solutes. For example, when we checked the effect of viscosity increase caused by additives, we found no significant impact on bioeffects.

It is possible that the nanoparticles were affected, including agglomeration, dampening of energy release from the nanoparticle due to a film of added compounds on the nanoparticle surface, or other effects. However, we do not think that these effects are the likely explanation for the observed increase in intracellular uptake while maintaining high viability. In a prior study, we looked at the effect of agglomerate size of CB nanoparticles and found that larger $\mathrm{CB}$ aggregates caused increased uptake but also decreased viability and was not associated with viability preservation. ${ }^{58}$ This suggests that increased aggregation of CB nanoparticles is not a likely explanation for the increased uptake with viability preservation seen here.

Moreover, when we reviewed our prior studies on photoporation, we found that changes to the laser input and the nanoparticle properties can broadly increase uptake. However, the uptake generally increases, peaks and then falls as the parameters are varied, because viability loss sets in at more aggressive conditions. ${ }^{11,13,14,18,59}$ This trend in the prior literature is consistent with the findings in the present study after photoporation without serum or other additives (eg, Figure 1, with no FBS). However, when we included protein and polymer additives in this study, we saw a different result: increasing laser fluence increased uptake, which then plateaued without decreasing at more aggressive conditions because viability loss did not set in. This suggests that the effects of these additives were not on the process of energy transfer to the cell but had to do with the cell's response to the energy transfer. For these reasons, we expect that there is an interaction between the cells and the added compounds that provide a protective effect. As discussed above, many prior studies have reached a similar conclusion that cells exposed to mechanical stresses (eg, from bubbles) can be protected by the addition of polymeric additives by a mechanism involving interaction with the cell membrane. More work will need to be done to more fully elucidate the mechanisms involved during photoporation in the presence of polymeric and other additives.

\section{Translational Considerations}

CB nanoparticle photoporation with polymeric viabilityprotecting additives may be useful for translational applications. There are a variety of methods to facilitate delivery of molecules to cells, and their optimization usually involves balancing efficient intracellular delivery with low loss of cell viability. Electroporation can be optimized by controlling electric pulses parameters, as well as modifying the cell medium during exposure. ${ }^{20,25,60}$ Sonoporation can similarly be optimized, but the sometimes violent nature of delivery by acoustic cavitation has resulted in difficulty keeping cells viable at strong conditions leading to efficient uptake. ${ }^{21}$ Microinjection can have very high delivery efficiency and cell viability, but suffers from extremely low throughput when injecting one cell at a time. ${ }^{61}$ Viral vectors and cationic lipid or polymer nanoparticles have been useful to facilitate intracellular delivery but are generally used only for genetic material, like DNA and RNA. ${ }^{62}$ In general, there is not a single intracellular delivery method that is optimal for all cells, molecules and applications. We believe that the viability protection shown in this study makes photoporation attractive alternative to the conventional delivery approaches.

Physical methods of intracellular delivery enhancement are often optimized by modulating energy input (eg, laser fluence, electric field strength, acoustic pressure), but often that is not enough. Changing the composition of the cell suspension medium provides an additional set of options 
for further optimization, as shown in this study. The observation that serum is protective of cells may mean that photoporation in vivo, where the cellular environment has proteins and other compounds that may be protective like serum is, could be inherently protective of cells without further additives. In other cases, adding inexpensive, routinely available and apparently otherwise-inert polymers like those studied here provides a simple and accessible approach to optimization.

\section{Conclusion}

Nanoparticle-mediated photoporation can be used for intracellular delivery of molecules in biotechnology, medical, and research applications. Physical creation of transient cell membrane pores often necessitates trade-offs between delivery and viability loss. Through this study, we showed that adding FBS to cells during laser irradiation can lower cell viability loss at high fluence. For example, the percentage of viable cells increased from less than $25 \%$ to greater than $80 \%$ only by the addition of FBS at certain laser exposure conditions, which allowed use of more aggressive photoporation conditions that significantly increased the percentage of viable cells with molecular uptake-for example, from less than $20 \%$ to more than $80 \%$ of exposed cells. In the absence of FBS, no more than $60 \%$ of exposed cells exhibited intracellular uptake over the range of conditions studied here. The protective effects of FBS were seen in two different cell types and required FBS to be present during laser exposure.

To better understand the protection mechanism, we found that only the high molecular weight fraction $(>30$ $\mathrm{kDa})$ of FBS was needed for protective efficacy, and that denatured FBS worked just as well as fresh FBS. Moreover, proteins such as albumin and hemoglobin present at similar concentrations as the protein present in the diluted FBS used in this study were also as protective as FBS. Finally, polymers including Pluronic F127, PVP, PEOX, and PEG were able to protect cell viability to varying extents; their effectiveness was increased by higher polymer concentration and molecular weight. Finally, protection of cell viability correlated positively with polymer hydrophobicity, suggesting that hydrophobic interactions with exposed cell membrane pores could play a role in the mechanism of protection.

Altogether, these findings suggest that the observed cell viability protection was caused by physical interactions between proteins or synthetic polymers with amphiphilic properties. We conclude that addition of certain polymers (including proteins) can protect cell viability during nanoparticle-mediated photoporation and thereby increase efficiency of intracellular delivery of molecules by a mechanism enhanced by increased polymer concentration, molecular weight, and hydrophobicity.

\section{Disclosure}

The authors report no conflicts of interest in this work.

\section{References}

1. Torchilin VP. Recent approaches to intracellular delivery of drugs and dna and organelle targeting. Annu Rev Biomed Eng. 2006;8 (1):343-375. doi:10.1146/annurev.bioeng.8.061505.095735

2. Xiong R, Samal SK, Demeester J, Skirtach AG, De Smedt SC, Braeckmans K. Laser-assisted photoporation: fundamentals, technological advances and applications. Adv Phys X. 2016;1(4):596-620. doi:10.1080/23746149.2016.1228476

3. Godbey WT An Introduction to Biotechnology: the Science, Technology and Medical Applications. Woodhead publishing; 2014:35-64. http://www.sciencedirect.com/science/article/pii/ B9781907568282000034. Accessed April 21, 2021.

4. Casem ML. Chapter 9 - Endocytosis. In: Casem ML, editor. Case Studies in Cell Biology. Problem Sets in Biological and Biomedical Sciences. Boston: Academic Press; 2016:217-240. doi:10.1016/ B978-0-12-801394-6.00009-9

5. Akinc A, Battaglia G. Exploiting Endocytosis for Nanomedicines. Cold Spring Harb Perspect Biol. 2017;5(11). doi:10.1101/cshperspect.a016980

6. Bareford LM, Swaan PW. Endocytotic mechanisms for targeted drug delivery. Adv Drug Deliv Rev. 2007;59(8):748-758. doi:10.1017/ CBO9781107415324.004

7. Pfeifer A, Verma IM. Gene therapy: promises and problems. Annu Rev Genomics Hum Genet. 2001;2(1):177-211. doi:10.1146/annurev. genom.2.1.177

8. Feng X, Tang Y, Duan X, Liu L, Wang S. Lipid-modified conjugated polymer nanoparticles for cell imaging and transfection. $J$ Mater Chem. 2010;20(7):1312-1316. doi:10.1039/B915112E

9. Alsaggar M, Liu D. Physical methods for gene transfer. Elsevier Ltd. 2015;89:1-24. doi:10.1016/bs.adgen.2014.10.001

10. Desai N. Challenges in development of nanoparticle-based therapeutics. AAPS J. 2012;14(2):282-295. doi:10.1208/s12248-012-9339-4

11. Chakravarty P, Qian W, El-Sayed MA, Prausnitz MR. Delivery of molecules into cells using carbon nanoparticles activated by femtosecond laser pulses. Nat Nanotechnol. 2010;5(8):607-611. doi:10.1038/nnano.2010.126

12. Sengupta A, Kelly SC, Dwivedi N, Thadhani N, Prausnitz MR. Efficient Intracellular delivery of molecules with high cell viability using nanosecond-pulsed laser-activated carbon nanoparticles. ACS Nano. 2014;8(3):2889-2899. doi:10.1021/nn500100x

13. Sengupta A, Gray MD, Kelly SC, Holguin SY, Thadhani NN, Prausnitz MR. Energy transfer mechanisms during molecular delivery to cells by laser-activated carbon nanoparticles. Biophys $J$. 2017;112(6):1258-1269. doi:10.1016/j.bpj.2017.02.007

14. Holguin SY, Gray MD, Joseph P, Thadhani NN, Prausnitz MR. Photoporation using carbon nanotubes for intracellular delivery of molecules and its relationship to photoacoustic pressure. Adv Healthc Mater. 2018;7(5):1701007. doi:10.1002/adhm.201701007

15. Kumar S, Chong C, Voorhees T, Thadhani NN, Prausnitz MR. Relationship between bio-effects and energy transduction during nanoparticle-mediated photoporation. J Appl Phys. 2020;128 (17):173101. doi:10.1063/5.0021834 
16. Dickerson EB, Dreaden EC, Huang X, et al. Gold nanorod assisted near-infrared plasmonic photothermal therapy (PPTT) of squamous cell carcinoma in mice. Cancer Lett. 2008;269(1):57-66. doi:10.1016/j.canlet.2008.04.026

17. Sengupta A, Mezencev R, McDonald JF, Prausnitz MR. Delivery of siRNA to ovarian cancer cells using laser-activated carbon nanoparticles. Nanomedicine. 2015;10(11):1775-1784. doi:10.2217/ nnm.15.27

18. Holguin SY, Thadhani NN, Prausnitz MR. Effect of laser fluence, nanoparticle concentration and total energy input per cell on photoporation of cells. Nanomed Nanotechn Biol Med. 2018;14 (5):1667-1677. doi:10.1016/j.nano.2018.04.015

19. Xiong R, Raemdonck K, Peynshaert K, et al. Laser-induced vapor nanobubbles for efficient delivery of macromolecules in live cells. Colloid Nanoparticles Biomed Appl X. 2015;9338 (March 2015):93381J. doi:10.1117/12.2078895

20. Canatella PJ, Karr JF, Petros JA, Prausnitz MR. Quantitative study of electroporation-mediated molecular uptake and cell viability. Biophys J. 2001;80(2):755-764. doi:10.1016/S0006-3495(01)76055-9

21. Liu Y, Yan J, Prausnitz MR. Can ultrasound enable efficient intracellular uptake of molecules? A retrospective literature review and analysis. Ultrasound Med Biol. 2012;38(5):876-888. doi:10.1016/j. ultrasmedbio.2012.01.006

22. Miller L, Leor J, Rubinsky B. Cancer cells ablation with irreversible electroporation. Technol Cancer Res Treat. 2005;4(6):699-705. doi:10.1177/153303460500400615

23. Kunas KT, Papoutsakis ET. Increasing serum concentrations decrease cell death and allow growth of hybridoma cells at higher agitation rates. Biotechnol Lett. 1989;11(8):525-530. doi:10.1007/BF01040029

24. Kunas KT, Papoutsakis ET. The protective effect of serum against hydrodynamic damage of hybridoma cells in agitated and surface-aerated bioreactors. $J$ Biotechnol. 1990;15(1-2):57-69. doi:10.1016/0168-1656(90)90051-C

25. Delteil C, Teissié J, Rols MP. Effect of serum on in vitro electrically mediated gene delivery and expression in mammalian cells. Biochim Biophys Acta. 2000;1467(2):362-368. doi:10.1016/S0005-2736(00) 00235-2

26. Han S-E, Kang H, Shim GY, et al. Novel cationic cholesterol derivative-based liposomes for serum-enhanced delivery of siRNA. Int $J$ Pharm. 2008;353(1-2):260-269. doi:10.1016/J. IJPHARM.2007.11.026

27. Shahabi S, Döscher S, Bollhorst T, et al. Enhancing cellular uptake and doxorubicin delivery of mesoporous silica nanoparticles via surface functionalization: effects of serum. ACS Appl Mater Interfaces. 2015;7(48):26880-26891. doi:10.1021/acsami.5b09483

28. Chalmers JJ. Mixing, aeration and cell damage, 30+ years later: what we learned, how it affected the cell culture industry and what we would like to know more about. Curr Opin Chem Eng. 2015;10:94-102. doi:10.1016/j.coche.2015.09.005

29. Park JH, Jackman JA, Ferhan AR, Ma GJ, Yoon BK, Cho N Temperature-Induced Denaturation of BSA Protein Molecules for Improved Surface Passivation Coatings. ACS Appl Mater Interfaces. 2018;10(38):32047-32057. doi:10.1021/acsami.8b13749

30. Stathopulos P, Scholz G, Hwang Y, Rumfeldt J, Lepock J, Meiering E. Sonication of proteins causes formation of aggregates that resemble amyloid.pdf. Protein Sci. 2004;13(11):3017-3027. doi: $10.1110 /$ ps.0483180

31. Sengupta A. Intracellular Drug Delivery Using Laser Activated Carbon Nanoparticles [Dissertation]. Georgia Institute of Technology; 2014

32. Lindl T. Zell- Und Gewebekultur. Heidelberg: Spektrum Akademischer Verlag; 2002. 5. doi:10.1007/978-3-642-35997-2

33. Michaels JD, Petersebt JF, Mclntire LV, Papoutsakis ET. Protection Mechanisms of Freely Suspended Animal Cells (CRL 8018) from Fluid-Mechanical Injury. Viscomet ric and Bioreactor Studies Using Serum, Pluronic F68 and Polyethylene Glycol. Biotechnol Bioeng. 1990;38:169-180. doi:10.1002/bit.260380209
34. Papoutsakis ET. Media additives for protecting freely suspended animal cells against agRation and aeration damage. Trends Biotechnol. 1991;9(1):316-324. doi:10.1016/0167-7799(91)90102-N

35. Luxenhofer R, Sahay G, Schulz A, et al. Structure-property relationship in cytotoxicity and cell uptake of poly(2-oxazoline) amphiphiles. J Control Release. 2011;153(1):73-82. doi:10.1016/j. jconrel.2011.04.010

36. Dini E, Alexandridou S, Kiparissides C. Synthesis and characterization of cross-linked chitosan microspheres for drug delivery applications. J Microencapsul. 2003;20(3):375-385. doi:10.1080/ 0265204031000093078

37. Sengupta A, Dwivedi N, Kelly SC, Tucci L, Thadhani NN, Prausnitz MR. Poloxamer surfactant preserves cell viability during photoacoustic delivery of molecules into cells. Biotechnol Bioeng. 2015;112(2):405-415. doi:10.1002/bit.25363

38. Shintani Y, Iwamoto K, Kitano K. Polyethylene glycols for promoting the growth of mammalian cells. Appl Microbiol Biotechnol. 1988;27(5-6):533-537. doi:10.1007/BF00451627

39. Poellmann MJ, Lee RC, Lee RC. Repair and Regeneration of the Wounded Cell Membrane. Regen Eng Soc. 2017;641:111-132. doi:10.1007/s40883-017-0031-1

40. Boucher E, Mandato CA. Plasma membrane and cytoskeleton dynamics during single-cell wound healing. Biochim Biophys Acta Mol Cell Res. 2015;1853(10):2649-2661. doi:10.1016/j. bbamcr.2015.07.012

41. Chattopadhyay D, Rathman JF, Chalmers JJ. Thermodynamic approach to explain cell adhesion to air-medium interfaces. Biotechnol Bioeng. 2003;20(3):649-658. doi:10.3109/ 02652040309178076

42. Xiong R, Samal SK, Demeester J, et al. Laser-assisted photoporation: fundamentals, technological advances and applications. Adv Phys $X$. 2016;6149(April2017):596-620. doi:10.1080/ 23746149.2016.1228476

43. Elzoghby AO, Samy WM, Elgindy NA. Albumin-based nanoparticles as potential controlled release drug delivery systems. J Control Release. 2012;157(2):168-182. doi:10.1016/j.jconrel.2011.07.031

44. Michaels JD, Nowak JE, Mallik AK, Koczo K, Wasan DT, Papoutsakis ET. Interfacial properties of cell culture media with cell-protecting additives. Biotechnol Bioeng. 1995;47:420-430.

45. Michaels JD, Nowak JE, Mallik AK, Koczo K, Wasan DT, Papoutsakis ET. Analysis of cell-to-bubble attachment in sparged bioreactors in the presence of cell-protecting additives. Biotechnol Bioeng. 1995;47(4):407-419. doi:10.1002/bit.260470402

46. Papra A, Gadegaard N, Larsen NB. Characterization of ultrathin poly (ethylene glycol) monolayers on silicon substrates. Langmuir. 2001;17(5):1457-1460. doi:10.1021/la000609d

47. Faibish RS, Yoshida W, Cohen Y. Contact angle study on polymer-grafted silicon wafers. J Colloid Interface Sci. 2002;256 (2):341-350. doi:10.1006/jcis.2002.8612

48. Qiu W, Sun X, Wu C, Hjort K, Wu Z. A Contact angle study of the interaction between embedded amphiphilic molecules and the PDMS matrix in an aqueous environment. Micromachines. 2014;5 (3):515-527. doi:10.3390/mi5030515

49. Bewersdorff T, Gruber A, Eravci M, Dumbani M, Klinger D, Haase A. Amphiphilic nanogels: influence of surface hydrophobicity on protein corona, biocompatibility and cellular uptake. Int J Nanomedicine. 2019;14:7861-7878. doi:10.2147/IJN.S215935

50. Clarke MS, McNeil PL. Syringe loading introduces macromolecules into living mammalian cell cytosol. J Cell Sci. 1992;102(3):533.

51. Hartikka J, Sukhu L, Buchner C, et al. Electroporation-facilitated delivery of plasmid DNA in skeletal muscle: plasmid dependence of muscle damage and effect of poloxamer 188. Mol Ther. 2001;4 (5):407-415. doi:10.1006/mthe.2001.0483

52. Raffa P, Wever DAZ, Picchioni F, Broekhuis AA. Polymeric surfactants: synthesis, properties, and links to applications. Chem Rev. 2015;115(16):8504-8563. doi:10.1021/cr500129h 
53. Lee H, Venable RM, MacKerell AD, Pastor RW. Molecular dynamics studies of polyethylene oxide and polyethylene glycol: hydrodynamic radius and shape anisotropy. Biophys J. 2008;95(4):1590-1599. doi:10.1529/biophysj.108.133025

54. Bharadwaj S, Vishnubhotla R, Shan S, Chauhan C, Cho M, Glover SC. Higher molecular weight polyethylene glycol increases cell proliferation while improving barrier function in an in vitro colon cancer model. J Biomed Biotechnol. 2011;2011. doi:10.1155/2011/ 587470

55. Lee RC. Cytoprotection by stabilization of cell membranes. Ann N Y Acad Sci. 2002;961:271-275. doi:10.1111/j.1749-6632.2002. tb03100.x

56. Wu J, Daugulis AJ, Faulkner P, Goosen MFA. Protective effects of polymer additives on animal cells exposed to rapidly falling liquid films. Biotechnol Prog. 1995;11(2):127-132. doi:10.1021/ bp00032a002

57. Merchant FA, Holmes WH, Capelli-Schellpfeffer M, Lee RC, Toner M. Poloxamer 188 enhances functional recovery of lethally heat-shocked fibroblasts. $J$ Surg Res. 1998;74(2):131-140. doi:10.1006/jsre.1997.5252
58. Kumar S, Lazau E, Prausnitz MR Intracellular drug delivery by nanoparticle mediated photoporation. Poster presented at: Annual meeting of The Nanomedicine and Drug Delivery Symposium, 2018, Portland OR.

59. Chakravarty P, Lane CD, Orlando TM, Prausnitz MR. Parameters affecting intracellular delivery of molecules using laser-activated carbon nanoparticles. Nanomed Nanotechn Biol Med. 2016;12 (4):1003-1011. doi:10.1016/j.nano.2015.12.380

60. Paganin-Gioanni A, Bellard E, Escoffre JM, Rols MP, Teissié J, Golzio M. Direct visualization at the single-cell level of siRNA electrotransfer into cancer cells. Proc Natl Acad Sci U S A. 2011;108(26):10443-10447. doi:10.1073/pnas.1103519108

61. Griesbach RJ. Chromosome-mediated transformation via microinjection. Plant Sci. 1987;50(1):69-77. doi:10.1016/01689452(87)90032-X

62. Amer MH. Gene therapy for cancer: present status and future perspective. Mol Cell Ther. 2014;2(27):1-19. doi:10.1186/2052$8426-2-27$

\section{Publish your work in this journal}

The International Journal of Nanomedicine is an international, peerreviewed journal focusing on the application of nanotechnology in diagnostics, therapeutics, and drug delivery systems throughout the biomedical field. This journal is indexed on PubMed Central, MedLine, CAS, SciSearch ${ }^{\mathbb{R}}$, Current Contents ${ }^{\mathbb{R}} /$ Clinical Medicine, $^{-}$
Journal Citation Reports/Science Edition, EMBase, Scopus and the Elsevier Bibliographic databases. The manuscript management system is completely online and includes a very quick and fair peer-review system, which is all easy to use. Visit http://www.dovepress.com/ testimonials.php to read real quotes from published authors. 